\title{
Poznań i jego mieszkańcy XIX wieku w pamiętnikarskim dziele Przechadzki po mieście Marcelego Mottego
}

Streszczenie. Artykuł prezentuje jedno z najważniejszych polskich dzieł pamiętnikarskich powstałych w XIX wieku - Przechadzki po mieście autorstwa Marcelego Mottego, zwanego „piewcą XIX-wiecznego Poznania” - w kontekście przedstawionego w nim obrazu miasta i jego mieszkańców. Autor w swych wspomnieniach na pierwszym miejscu postawił opowieść o ludziach, natomiast miasto, jego ulice i place jako teren kolejnych przechadzek są niejako kanwą narracji. Niezwykłe walory dzieła, takie jak komunikatywność, bogactwo języka, poczucie humoru, anegdota w przekazie, wraz z ogromem informacji na temat miasta i jego obywateli (wszystkich funkcjonujących w nim narodowości), w tym zwłaszcza warstw ziemiaństwa, inteligencji, mieszczaństwa sprawiaja, że dzieło stanowi wyjątkowe źródło pamiętnikarskie, z którego głębi, ujawniającej się w każdorazowej lekturze, czerpią historycy, przewodnicy miejscy oraz wszyscy zainteresowani dziejami stolicy Wielkopolski XIX stulecia.

SŁowa Kluczowe: pamiętniki, Marceli Motty, Przechadzki po mieście, Poznań, biografie.

\section{Wprowadzenie}

W XIX wieku obserwuje się szczególny rozkwit twórczości pamiętnikarskiej $^{1}$, na który niewątpliwy wpływ wywarł romantyzm, inspirując przedstawicieli różnych warstw społecznych, zwłaszcza arystokracji, ziemiaństwa czy inteligencji, by sięgnęli po pióro. Każdy kolejny wstrząs

1 F. Jakubczak, Jak pisać, pozyskiwać i użytkować pamiętniki, „Pamiętnikarstwo Polskie" 1971, nr 1, s. 151. Autor wyróżnia wśród zapisów pamiętnikarskich kilka gatunków. 
historyczny w XIX stuleciu wywoływał falę spisywanych wspomnień. Obfity plon pod tym względem przyniosło powstanie listopadowe ${ }^{2}$. U schyłku stulecia natomiast pojawiały się często relacje wspomnieniowe, które przedstawiały działalność autorów na polu społecznym, gospodarczym czy kulturalnym. Były one, w przeciwieństwie do dawniejszych pamiętników, przeznaczone do natychmiastowej publikacji. Powstawanie tego typu utworów sygnalizowało dewaluację przeżycia osobistego czy słabnący napór wydarzeń historycznych zmieniających znacząco przebieg życia prywatnego. W tekstach często wykorzystywano formę gawędy, która wiązała się na ogół z umiejętnością kreślenia ludzkich portretów ${ }^{3}$.

Autorzy pamiętników zwykle decydowali się je pisać u schyłku życia lub po okresie wielkich przemian. Ukształtowała się w związku z tym dwupłaszczyznowość narracji: autor mógł nie tylko opowiadać o przebiegu zdarzeń, ale też ujawniać swe stanowisko wobec nich w momencie pisania. Pamiętnik różni się także zasadniczo od tekstu autobiograficznego czy dziennika tym, że nie analizuje, nie akcentuje intymnego świata osoby piszącej, lecz stanowi relację przede wszystkim z wydarzeń zewnętrznych. Często, choć nie zawsze, wydarzenia są omawiane chronologicznie ${ }^{4}$. Relacje mogą mieć charakter autorski (gdy piszący był bezpośrednim uczestnikiem zdarzeń lub ich świadkiem) lub wtórny (gdy relację pozyskał z drugiej ręki). A biorąc pod uwagę kompozycję wspomnieniowa, można napotkać metodę relacji uteraźniejszonej, retrospektywnej, różnoczasowej. Według koncepcji Zbysława Wojtkowiaka dziennik jako na bieżąco spisywana relacja jest relacją autorską uteraźniejszoną kronika domowa zawierająca również treści z drugiej ręki może być określona jako relacja autorska, wtórna, uteraźniejszona. Autobiografia, pisana po latach, jest relacją autorską, retrospektywna, natomiast pamiętnik - relacją autorska, wtórna, retrospektywną. $\mathrm{Na}$ sporządzenie ostatniej z wymienionych relacji zdecydował się niemal u schyłku swego życia Marceli Motty. Zapewniła mu ona sławę i uznanie za życia i po śmierci.

2 Oprócz przywódców zapiski pozostawiali oficerowie, nawet zwykli żołnierze, by dać świadectwo wydarzeń, w których wzięli udział, kierowała nimi potrzeba stworzenia pełnego obrazu czynu zbrojnego. Autorami pamiętnika zwanego politycznym w Poznańskiem byli: Henryk Szuman, Aleksander Guttry, Jan Nepomucen Niemojowski, Władysław Kosiński czy Józef Garczyński.

3 M. Dernałowicz, Pamiętnikarstwo, w: Słownik literatury polskiej XIX w., red. J. Bachórz, A. Kowalczykowa, Warszawa 2002, s. 670-674.

4 Z. Wojtkowiak, Nauki pomocnicze historii najnowszej. Źródła narracyjne. Pamiętnik, tekst literacki, cz. 1, Poznań 2001, s. 52-53.

5 Ibidem. 


\section{Marceli Motty - portret poznańskiego pamiętnikarza}

Osiemdziesiąt lat życia, spędzonego na pożytek społeczeństwa, daje mu pełne prawo do wdzięcznej pamięci ${ }^{6}$.

Marceli Motty przyszedł na świat 5 czerwca 1818 roku w Poznaniu, w poznańskiej rodzinie inteligenckiej jako pierworodny syn Jana Baptysty Francuza o włoskich korzeniach przybyłego do Wielkopolski z Paryża oraz Apolonii z Herwigów o polsko-niemieckim pochodzeniu. Małżeństwo doczekało się prócz syna Marcelego także córki Walentyny (1823-1859), późniejszej żony Hipolita Cegielskiego, oraz drugiego syna - Stanisława (1826-1900), późniejszego sędziego i posła do sejmu pruskiego w Berlinie.

Marceli ukończył Gimnazjum św. Marii Magdaleny w Poznaniu. Następnie filologię klasyczną na Uniwersytecie Berlińskim, którą uwieńczył w 1840 roku pracą doktorską z mitologii antycznej oraz egzaminami uprawniającymi do nauczania

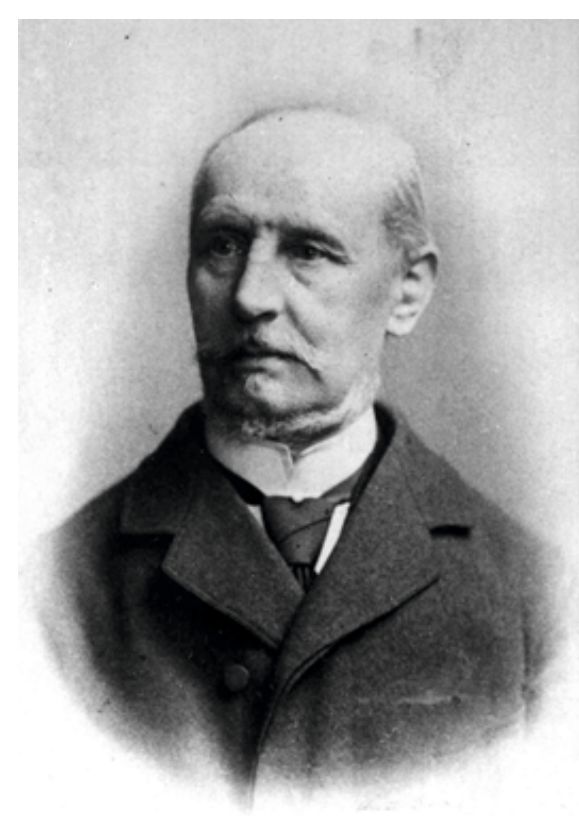

Il. 1. Marceli Motty Źródło: zbiory autorki. w gimnazjum. Pracę nauczycielską rozpoczął w 1841 roku w Szkole Realnej w Międzyrzeczu. W 1842 roku uzyskał stypendium rządowe na roczny pobyt w Paryżu w celu doskonalenia wiedzy zawodowej i znajomości języka francuskiego. Wyjazd pozwolił mu poznać ojczyznę ojca, środowisko artystyczne i naukowe stolicy Francji oraz przedstawicieli polskiej emigracji. Spostrzeżenia zawarł $\mathrm{w}$ listach opublikowanych $\mathrm{w}$ formie felietonów w "Orędowniku Naukowym”. Po powrocie do Poznania rozpoczął pracę dydaktyczną w Gimnazjum Fryderyka Wilhelma, a następnie w Gimnazjum św. Marii Magdaleny. Po trzech latach wraz ze szwagrem Hipolitem Cegielskim i innymi nauczycielami za odmowę dokonania rewizji w domach uczniów został zwolniony z posady, co w konsekwencji zmusiło go do podjęcia próby zmiany zawodu. Zdecydował się zdobyć

6 Słowa Antoniego Danysza zamieszczone na tablicy pamiątkowej poświęconej Marcelemu Mottemu, ufundowanej przez Koło Przewodników PTTK. 


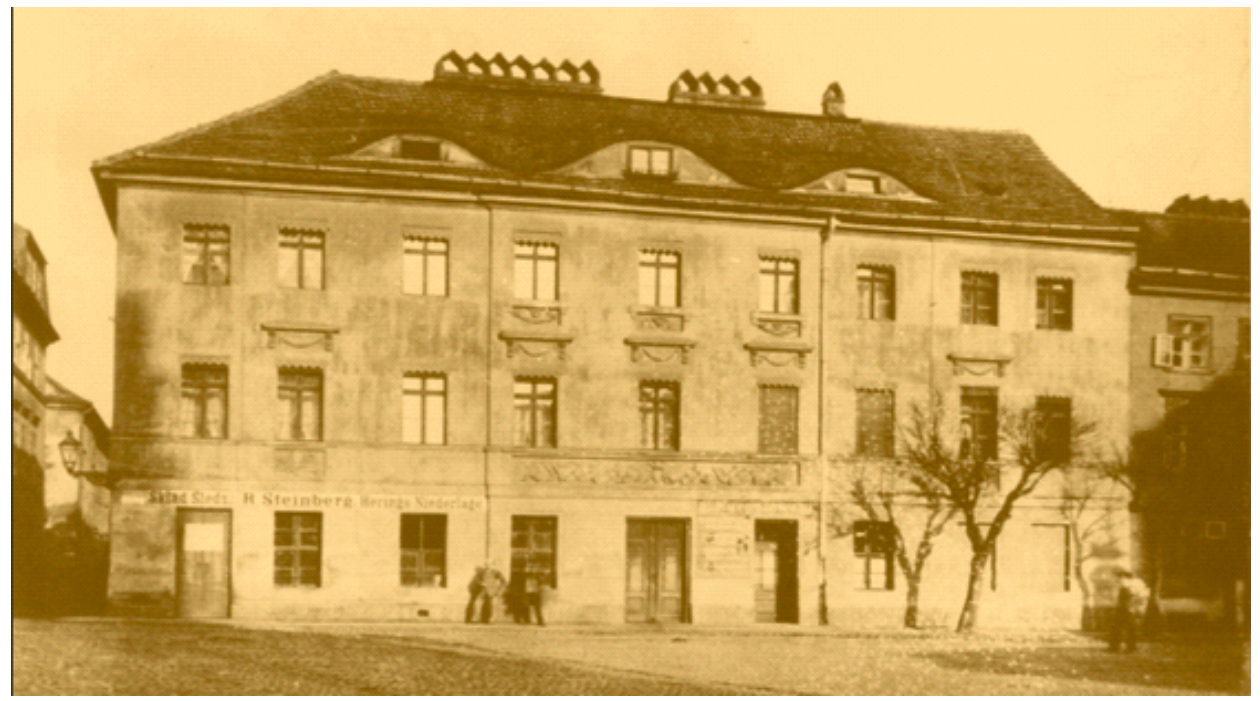

Il. 2. Kamienica Bergera (obecnie Hotel Kolegiacki) przy pl. Kolegiackim 5, w której mieszkał w latach młodości Marceli Motty. Na ścianie kamienicy od 1995 roku znajduje się tablica upamiętniająca autora Przechadzek po mieście Źródło: zbiory autorki.

kwalifikacje na urzędnika leśnego. Odbył praktykę zawodową oraz studia w Akademii Leśnej w Neustadt-Eberswalde. Nowa specjalizacja jednak nie pociągała go tak jak zawód nauczycielski. Wiosna Ludów zmieniła jego sytuację. Zrezygnował z dalszej edukacji w Neustadt-Eberswalde, z zapałem podjął się funkcji redaktora "Gazety Polskiej” założonej przez Hipolita Cegielskiego. W 1849 roku ożenił się z ziemianką Walerią z Bukowieckich. Niedługo potem, w 1850 roku szczęśliwie znów mógł objąć etat nauczyciela w Gimnazjum św. Marii Magdaleny. Pełnię dojrzałości zawodowej osiągnął w Szkole Realnej w Poznaniu, do której przeniósł się wkrótce po jej powstaniu w 1853 roku i gdzie spędził 34 lata pracy. W szkołach nauczał: języka łacińskiego, francuskiego i historii. Cieszył się poważaniem uczniów oraz społeczności Poznania. Przez ponad pół wieku parał się tłumaczeniem na język polski dzieł poetów starożytnych (Horacego, Wergiliusza, Owidiusza, Arystofanesa). Największą sławę jednak przyniosły mu publikowane w latach 1865-1867 felietony z cyklu De omnibus rebus..., znane jako Listy Wojtusia z Zawad, ze swadą komentujące współczesne wydarzenia i obyczajowość. A później trwałe miejsce w pamięci potomnych i miano "piewcy XIX-wiecznego Poznania” zapewniło mu pamiętnikarskie dzieło Przechadzki po mieście, traktowane jako źródło historyczne do badań nad Poznaniem i jego mieszkańcami XIX wieku. Marceli Motty mimo wielu obowiązków zawodowych znajdował czas na 
działalność społeczną. W 1844 roku związał się z Towarzystwem Pomocy Naukowej, współpracując z jego twórcą - dr. Karolem Marcinkowskim. Należał do grona założycieli i działaczy Poznańskiego Towarzystwa Przyjaciół Nauk. Chętnie udzielał się także w Kole Towarzyskim, wygłaszając prelekcje, organizując imprezy kulturalne i towarzyskie.

Stworzył wraz z żoną Walerią szczęśliwą rodzinę. Doczekał się sześciorga dzieci (trzech córek i trzech synów). Czworo zmarło przedwcześnie, ojca przeżyło tylko dwóch synów: Jan (1850-1924) i Karol (1856-1928).

Zmarł 17 stycznia 1898 roku. Jego pogrzeb zmienił się w manifestację społeczeństwa poznańskiego licznie przybyłego, by pożegnać wspaniałego człowieka, nauczyciela oraz znawcę i miłośnika swej epoki. Po latach, w 1981 roku Koło Przewodników PTTK w Poznaniu wybrało Marcelego Mottego na swego patrona i do dziś w różnorodny sposób kultywuje jego pamięć i dokonania ${ }^{7}$.

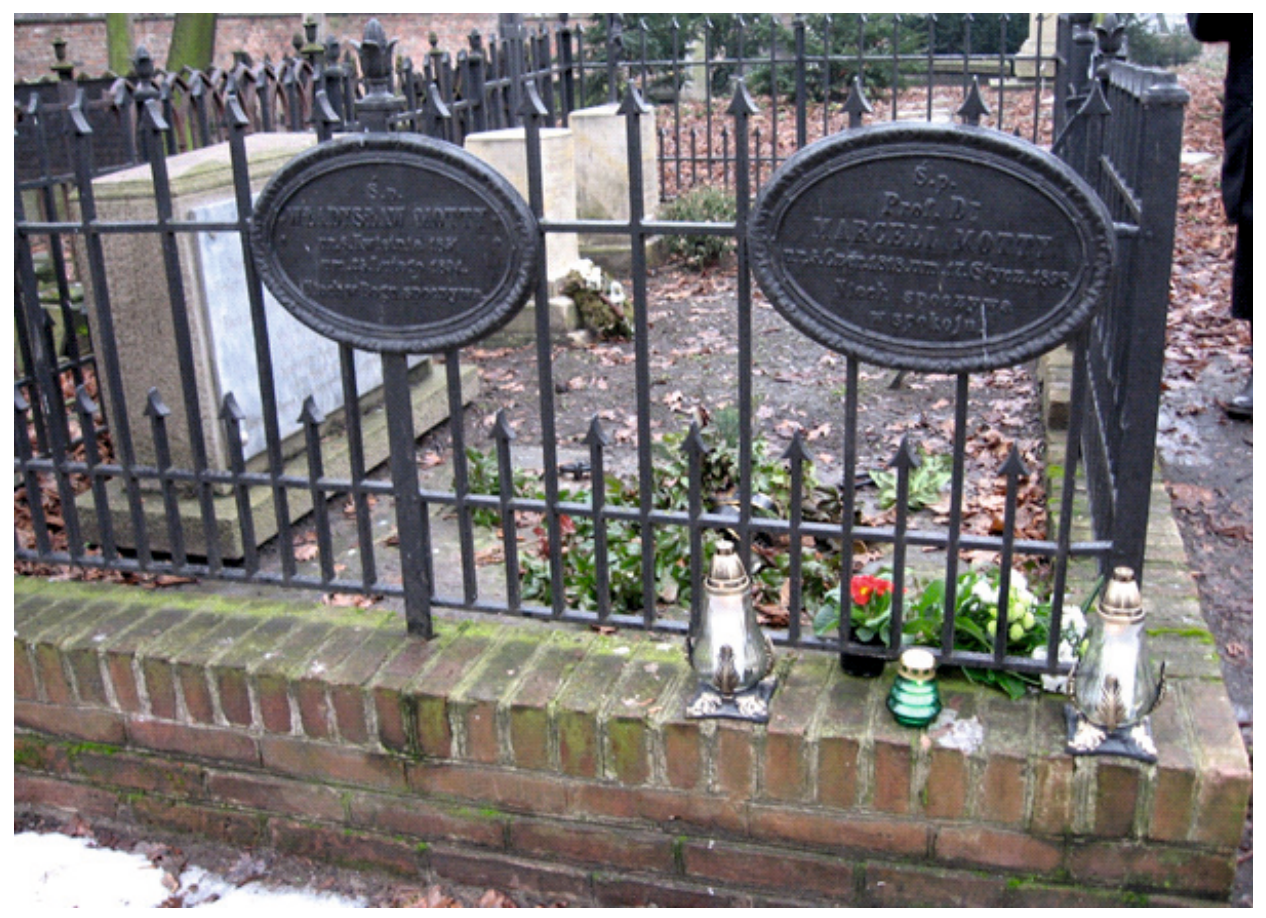

Il. 3. Grób rodziny Mottych na Cmentarzu Zasłużonych na Wzgórzu Świętego Wojciecha w Poznaniu

Źródło: zbiory autorki.

7 Szerzej biografia i formy upamiętniania Marcelego Mottego jako patrona Koła Przewodników PTTK w Poznaniu: I. Wyszowska, Marceli Motty (1818-1898): poznański nauczyciel, felietonista i pamiętnikarz, Poznań 2008. 


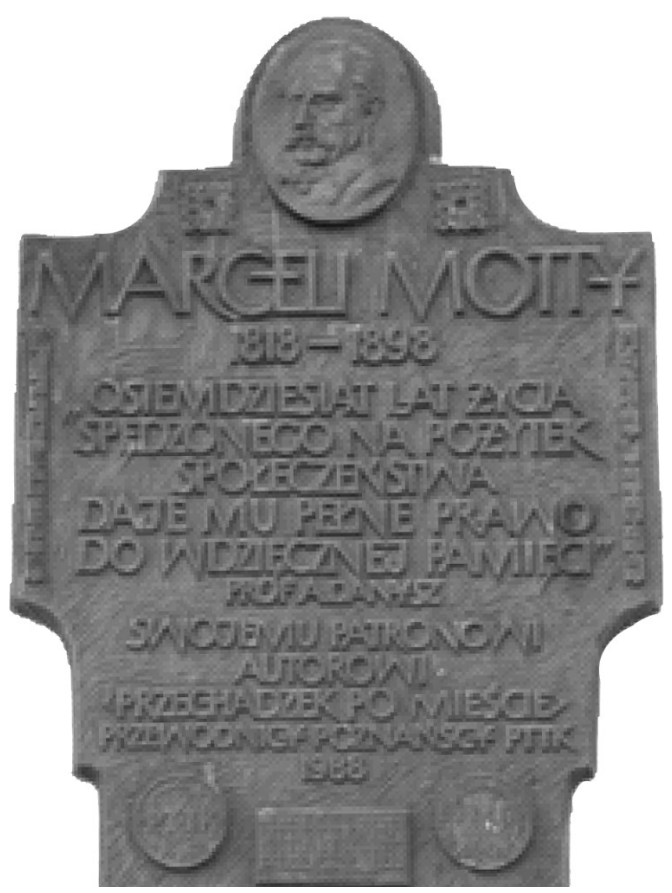

Il. 4. Tablica pamiątkowa fundacji Koła Przewodników PTTK im. M. Mottego w Poznaniu, na ścianie dawnej kamienicy Bergera przy pl. Kolegiackim 5 Źródło: zbiory autorki.

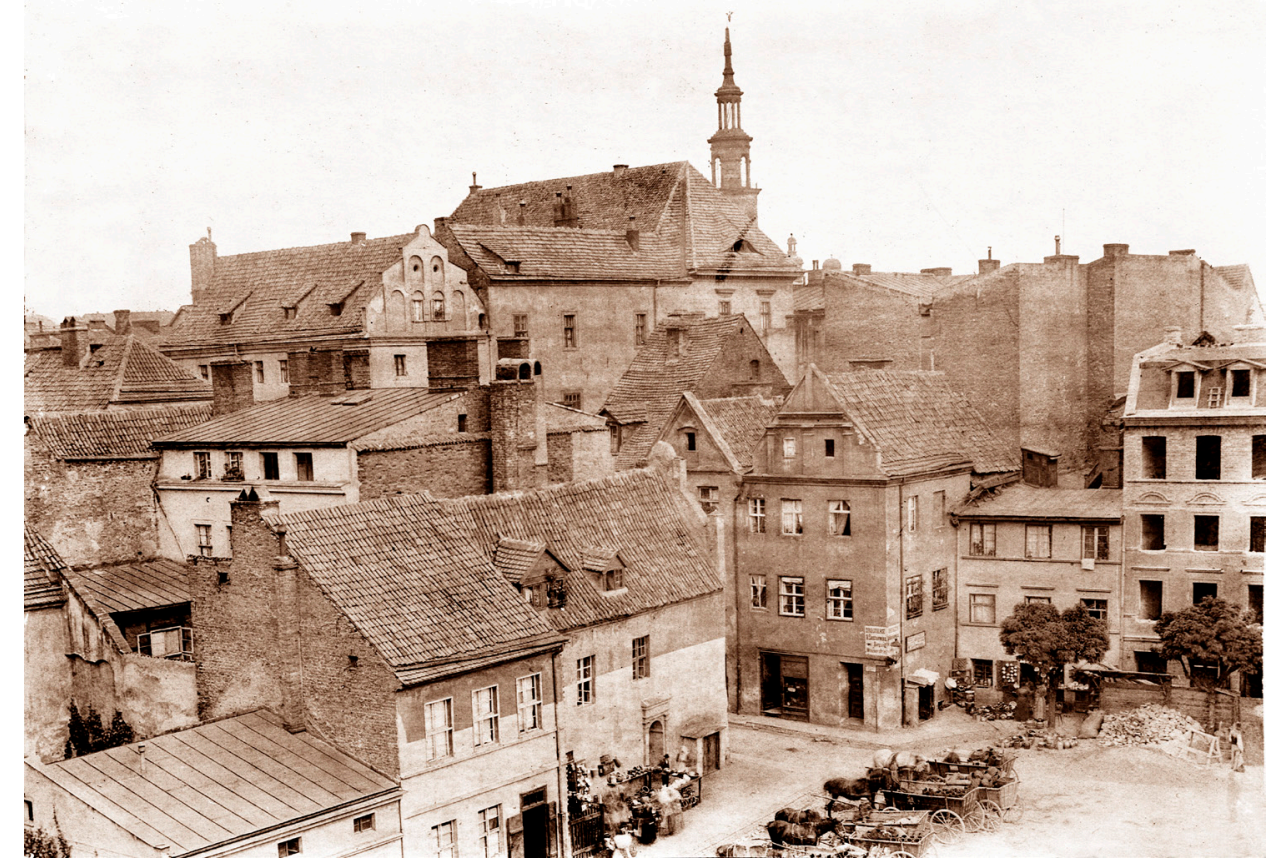

Il. 5. Nowy Rynek - fotografia Friedricha Dahmsa z około 1900 roku Źródło: zbiory Biblioteki Uniwersyteckiej w Poznaniu. 


\section{Przechadzki po mieście - geneza i charakterystyka dzieła}

Żadne z miast polskich nie doczekało się tak pięknego dowodu miłości ${ }^{8}$.

Dnia 17 stycznia w numerze 13 „Dziennika Poznańskiego” ukazał się pierwszy tekst z cyklu Przechadzki po mieście . Marceli Motty, jako emerytowany profesor Szkoły Realnej, nie przypuszczał wtedy, że właśnie te zapiski, wydane w przyszłości w całości, przyniosą mu uznanie za życia i wdzięczną pamięć następnych pokoleń. Za pióro chwycił niemal równocześnie z przejściem na emeryturę. Trudno dziś jednoznacznie stwierdzić, jakimi motywami kierował się, rozpoczynając nowe literackie wyzwanie. Można sądzić, iż potrzeba pozostawienia po sobie wspomnień dojrzewała w nim dużo wcześniej, wreszcie przyszedł właściwy czas, aby ją zrealizować. Tęsknota za przeszłościa, młodością, dawnym Poznaniem i ludźmi, którzy tworzyli atmosferę i koloryt miasta, uwidoczniła się u niego już w poprzednich felietonach. Powoli odchodzili jego najbliżsi. Przedwczesna śmierć córek na pewno była szczególnie bolesna. Krótko przed momentem rozpoczęcia Przechadzek Motty dotkliwie przeżył śmierć córki Marii (maj 1887) i przyjaciela Władysława Bentkowskiego (październik 1887). Te okoliczności mogły zainspirować go do pisania. Choroba żony i syna Władysława z pewnością nasuwały myśli o nieuchronności przemijania i potrzebie utrwalenia dla przyszłych pokoleń wspomnień o ludziach, miejscach i wydarzeniach.

Zdaniem Zdzisława Grota nasilający się z każdym rokiem ucisk germanizacyjny pogłębiający pesymizm i przygnębienie, powodujący zobojętnienie na sprawy publiczne i zamykanie się polskiego społeczeństwa we własnej prywatności, mógł też mieć wpływ na Mottego ${ }^{10}$. Zapewne czuł on, że nie może pozostać obojętnym w tej sytuacji. Najlepszym

8 L. Trzeciakowski, „Kwiat narodu”. Polska inteligencja Poznania XIX wieku, „Kronika Miasta Poznania" 1998, nr 2, s. 47.

9 „Dziennik Poznański” 1888, nr 13. Następny pojawił się w roku 1888, w nr. 20, potem nastąpiła przerwa do roku 1888 (nr 110). Przechadzki po mieście wychodziły nieregularnie, po okresach wzmożonej publikacji następowała przerwa. Ostatecznie edycja zakończyła się w 1891 roku. W międzyczasie pojawiały się informacje reklamujące wydania w częściach (od I do V) Przechadzek nakładem „Dziennika Poznańskiego”, m.in. „Dziennik Poznański” 1888, nr 234; „Dziennik Poznański” 1889, nr 82.

10 Z. Grot, Posłowie, w: M. Motty, Przechadzki po mieście, Warszawa 1957, s. 496. W. Dworzaczek, Pamiętniki wielkopolskie XVI-XIX wieku, „Nurt” 1973, nr 3, s. 32, wymienia przyczyny najczęściej skłaniające ludzi do spisania wspomnień: przełomowe chwile w dziejach kraju, przeżycia osobiste, przygody, koleje kariery, chęć opowieści o swym życiu dzieciom i wnukom. 
sposobem na pokrzepienie serc było więc przypomnienie dawnych, dobrych czasów, za które uważał pierwszą połowę XIX wieku, pokazanie jego zasłużonych obywateli, jako wzory do naśladowania w trudnej sytuacji dziejowej. Wielu z nich upamiętniał już wcześniej, poświęcając im, drukowane w poznańskiej prasie, obszerne nekrologi. O potrzebie pisania na temat wybitnych jednostek pisał w 1878 roku:

Niewdzięcznością byłoby i szkodą publiczną rzucać w otchłań niepamięci zasługi takich mężów, skoro ich śmierć wydrze społeczeństwu, owszem ciągle wskazywać trzeba następnym pokoleniom na światło tryskające z ich życia, na naukę płynącą z ich czynów. Są oni w pochodzie narodu drogowskazami poniekąd, naznaczającymi kierunek, którego się trzymać powinien, aby nie błądził; trzeba je zawsze mieć przed oczyma. Było wśród nas, w ostatnim lat okresie, wielu takich mężów, których górujące zasługi w obrębie narodowej pracy, za życia nie bez ciężkiej walki nabyte, społeczność teraźniejsza w wdzięcznej pamięci uprzytomniać sobie, a następcom jako zbawienne wzory pokazywać musi abyśmy i my i potomkowie, zwłaszcza iż coraz cięższa niedola, i bytu nie stracili i nie zgasili narodowego znicza ${ }^{11}$.

Okres, który Motty ożywił w swoich wspomnieniach, zamyka się mniej więcej w przedziale od 1825 do 1875 roku $^{12}$. Obejmuje problematykę powstań narodowych, pracy organicznej i jej wybitnych przedstawicieli, rozkwitu kulturalnego Poznania, zwanego „złotym okresem”, a więc młodości i dojrzałych lat Mottego. Charakterystyczne jest bowiem, jak twierdzi Włodzimierz Dworzaczek, że

niemal z reguły każdemu staremu gawędziarzowi prawiącemu o przeszłości zdawało się, że czasy, kiedy on był młody, miały jakiś szczególniejszy urok, były lepsze i szczęśliwsze od tych, w których przyszło mu pędzić starość. Nawet ci spośród pamiętnikarzy, którzy ongiś walczyli z istniejącymi stosunkami społecznymi czy politycznymi, którzy w nich widzieli samo tylko zło, nie przestawali być w gruncie rzeczy przysłowiowymi chwalcami czasów minionych ${ }^{13}$.

Z twórczością pamiętnikarską swoich poprzedników Motty stykał się niejednokrotnie. Jako felietonista czuł się zobowiązany do bycia na bieżąco z nowinkami wydawniczymi, a recenzje ze swej lektury zamieszczał

${ }^{11}$ M. Motty, Wspomnienie o śp. Prałacie Brzezińskim, Poznań 1878, s. 3.

${ }^{12}$ Poza ten okres wychodzi w sytuacji, kiedy narracja tego wymaga, np. w biografiach postaci, nawiązaniach do czasów napoleońskich, Polski szlacheckiej.

${ }^{13}$ W. Dworzaczek, op.cit., s. 32. 
w De omnibus rebus... Być może już wówczas kreował wizję swych przyszłych wspomnień. Niewykluczone, iż gromadził materiały w postaci wycinków prasowych, dokumentów, które zamierzał wykorzystać w późniejszym dziele. O Wspomnieniach Andrzeja Edwarda Koźmiana wyraził się następująco:

Pamiętniki te, pisane stylem poprawnym, jasnym i ozdobnym, są ważnym materiałem do dziejów Królestwa Kongresowego, podają nam osobliwie zajmujący obraz wyższego społeczeństwa warszawskiego z owych czasów i mnóstwo ciekawych szczegółów, tyczących się osób, które od 1815 do 1830 odznaczały się w tym społeczeństwie pod jakimkolwiek bądź względem ${ }^{14}$.

W ocenie zawarta jest aprobata takiego typu pamiętnika, jego treści i znaczenia jako przyszłego źródła. Tego rodzaju tekst mógł być dla Mottego inspirujący.

Przechadzki po mieście od początku przewidziane do upowszechnienia nie są więc pamiętnikiem typu osobistego, intymnego, "do szuflady". Adresatami były środowiska ziemiańskie i inteligenckie - czytelnicy „Dziennika Poznańskiego”. Motty kierował swe wspomnienia zarówno do swych rówieśników, którzy pamiętali jeszcze minioną epokę, jak i do młodych, z których grona wybrał fikcyjnego pana Ludwika - towarzysza przechadzek i słuchacza jego opowieści. Marceli pełni funkcję swoistego cicerone, oprowadzając po rodzinnym mieście tajemniczego młodzieńca, syna rzekomego przyjaciela ze szkolnej ławy, absolwenta Uniwersytetu Wrocławskiego, który powróciwszy po studiach prawniczych do Poznania, rozpoczął karierę referendarza w tutejszym sądzie. Pan Ludwik nadmienił, że już jako chłopiec chętnie czerpał z wiedzy swego „przewodnika", lepiej czując się w towarzystwie osób dojrzałych niż rówieśników, czym zasugerował czytelnikowi bezcenną wartość doświadczenia nabywanego z wiekiem.

Sędziwy narrator lubił codzienne „odbywanie polonezów po ulicach" z powodów, jak twierdził, zdrowotnych, bo to ,jeden z najpewniejszych i najtańszych środków higienicznych - podtrzymywania i krzepienia starych organizmów"15, chętnie więc przyjął dla swej narracji konwencję przechadzki. Jest to interesujący zabieg, dzięki któremu tok wspomnień

${ }^{14}$ M. Motty, Listy Wojtusia z Zawad, oprac. Z. Grot, T. Nożyński, Warszawa 1983, List XLIII, s. 460.

${ }^{15}$ M. Motty, Przechadzki po mieście, oprac. Z. Grot, W. Molik, t. 1-2, Poznań 1999, t. 1, s. 4. Dalej cytuję to wydanie. Motty lubił spacerować w towarzystwie Mikołaja Magnuszewicza, administratora Bazaru i zarządcy hotelu, mógł to czynić do jego śmierci w 1884 roku (s. 79). 
jest wolny od reguł chronologii i porządku rzeczowego. Poszczególne wątki układają się przypadkowo, inicjują je mijane obiekty, miejsca, ulice.

Przechadzki po mieście pod względem kompozycyjnym podzielone są na pięć części. Każda z nich jest relacją z jednego spaceru w określonej części miasta. Pierwsza obejmuje Stary Rynek, trasa przebiega dzisiejszą ul. Paderewskiego, przez Aleje Marcinkowskiego, pl. Wielkopolski, na Wzgórze św. Wojciecha. Druga rozpoczyna się na pl. Wolności, obejmuje ul. 27 Grudnia i ul. Mielżyńskiego, by zakończyć się na pl. Cyryla Ratajskiego. Trzecia biegnie ul. Św. Marcin, ul. Ogrodową, ul. Podgórna, przez pl. Wiosny Ludów, na ul. Półwiejską. Czwarta przechadzka obejmuje jedynie ul. Wrocławską i ul. Gołębią a ostatnia rozpoczyna się na pl. Kolegiackim, uwzględnia ul. Wodna, pl. Bernardyński i ul. Garbary. Niestety autor z nieznanych powodów pominął m.in. Chwaliszewo, Ostrów Tumski i Śródkę. Być może zamierzał tam się udać, nie stronił bowiem w swych wcześniejszych felietonach od tych obszarów miasta. Możliwe, że planował kontynuację dzieła, lecz siły na to już nie pozwoliły ${ }^{16}$.

Motty starał się uwiarygodnić swe fikcyjne przechadzki przez świadome zabiegi stylistyczne. Usprawiedliwiał konieczność zakończenia każdej z nich. Po pierwszym spotkaniu pisał: „proszę cię o urlop na kilka tygodni, a jak wrócę, włóczyć się znów będziem, jeśli cię to bawi, w innych stronach miasta"17. Po trzeciej przechadzce sugerował zmęczenie i konieczność odpoczynku po trudach wspólnej eskapady: „tym razem chodziliśmy i nagadaliśmy się trochę więcej niż w poprzednich wycieczkach, nie weźmiesz mi więc za złe, jeśli ze względu na ciebie i na siebie wspólne przechadzki nasze na czas niejaki zawieszę i wypocznę po trudach"18. Z takiej kompozycji jasno wynika, że Motty nie zamierzał pisać autobiografii czy kroniki, bowiem nie zachowuje chronologii. Ponadto autor nie eksponuje swojej osoby, a swą działalność społeczną skrzętnie ukrywa. O sobie i swej rodzinie mówi jak o osobach postronnych mimo przekazywania sporej dawki faktografii. Tak pisze o ojcu i jego synach (czyli o sobie i bracie Stanisławie): „do najdawniejszych za mej pamięci komorników w tej kamienicy należał profesor Jan Motty [...]. Był on we

16 „Kurier Poznański” 1898, nr 14. We wspomnieniu po śmierci Mottego podano następującą informację: „W literaturze swojskiej jednak imię jego pozostanie najbardziej znane jako autora słynnych Przechadzek po mieście, których dotychczas wyszło tomów pięć, a o ile wiemy, pozostał jeszcze w manuskrypcie materiał na tom szósty, którego nieboszczyk za życia publikować nie chciał"!

17 M. Motty, Przechadzki..., t. 1, s. 157.

${ }^{18}$ Ibidem, s. 470. Usprawiedliwienia te „wyjaśniały” też przerwę w publikowaniu kolejnych odcinków Przechadzek. 
wszystkich klasach moim nauczycielem i [...] prócz tego żyłem w przyjaźni z jego synami, a ze starszym przebywszy razem czasy gimnazjalne, kolegowałem jeszcze na uniwersytecie $[\ldots]^{\prime 19}$.

Czas narracji dzieła zamyka się w okresie około trzech lat. Przed rozpoczęciem piątej przechadzki autor pisał: „Nagabywałeś mnie już kilka razy, panie Ludwiku, abyśmy tę naszą Odyseję poznańską przed trzema laty rozpoczętą skończyli $[\ldots]^{\prime 20}$. Przechadzki tracą jednak pozory realizmu przez zbytnią obszerność relacji. Podczas każdego ze spacerów ilość przekazywanych treści przekraczała rzeczywisty czas, w którym mogłyby się odbywać. Narrator posłużył się w przekazie modną formą gawędy. Próbował wprowadzić elementy dialogu, lecz współtowarzysz - pan Ludwik - niewiele się ujawnia, jest raczej biernym słuchaczem.

Jak wcześniej powiedziano, w Przechadzkach po mieście mamy do czynienia z relacją autorską i wtórną. Motty deklaruje, że przekazywane fakty są mu znane z autopsji lub zasłyszane. Wyraźnie zaznacza, które z przekazywanych treści pochodzą z jego osobistego doświadczenia, a które pozyskał z innych źródeł. Pisał np.: "sam widziałem”, „znałem go osobiście”, „ile pomnę", ,jak sobie przypominam” lub „chodziła gadka”, "mówiono mi”, "opowiadał mi ojciec", „dowiedziałem się". W kilku miejscach charakteryzował stan swej pamięci, by odbiorca mógł mieć świadomość stopnia wiarygodności wspomnień: „nie recytuję Ci tutaj historii, lecz wspominam to i owo, co mi, patrzącemu lub słuchającemu utkwiło w zużytej już znacznie pamięci"21. W innym miejscu na ten temat pisał: „Wystaw sobie, panie Ludwiku, co to za dziwaczny przyrząd ta pamięć ludzka! Tysiące ważnych, mądrych i przydatnych rzeczy, których się długo i często uczyłem, zapomniałem niepowrotnie, a niejeden szczegół całkiem obojętny, niejedno głupstwo tak dobrze mi się przechowały w którejś z komórek mózgowych, iż od lat kilkudziesięciu siedzą tam sobie spokojne i bezpieczne" ${ }^{22}$. To stwierdzenie pozwala Mottemu zarezerwować dla swych wspomnień margines błędu i uchronić przed ewentualnymi atakami czytelników. Jest to sygnał także dla badacza dziejów XIX-wiecznego Poznania, by ostrożnie podchodzić do dzieła pamiętnikarskiego jako źródła historycznego. Zwłaszcza

${ }^{19}$ Ibidem, t. 2, s. 219-220.

${ }^{20}$ Ibidem, s. 161.

${ }^{21}$ Ibidem, t. 1, s. 117; s. 362: „Nie masz mnie uważać za historyka, mniej jeszcze za apologetę, już ci to kilka razy mówiłem; otóż powtarzam znowu, iż chodząc z tobą i rozprawiając, ograniczam się tylko na wynurzaniu ci wrażeń i wspomnień rozbudzonych widokiem ulic i domów, jako też myślą o znanych mi osobach, które mnie dawniej ożywiały".

${ }^{22}$ Ibidem, s. 129. 
faktografia domaga się weryfikacji. Problematyka obyczajowa oraz atmosfera epoki mogą być natomiast w o wiele większym stopniu potraktowane miarodajnie.

Jak już powiedziano, w swym dziele Marceli Motty zawarł elementy autobiograficzne, jednakże dość zakamuflowane. Wprost niewiarygodny jest fakt, że Motty nie znał dokładnego miejsca swego urodzenia, być może nie chciał ujawnić tego z jakiegoś powodu; pisał o tym tak: „jedna z nich [kamienica między ul. Wroniecką a Żydowską - I.W.] wsławiła się jako miejsce urodzenia niniejszego sługi twego, ale nie wiem już doprawdy która, bo temu historycznemu wypadkowi nigdy nie przypisywałem wielkiego znaczenia" ${ }^{23}$. O sobie pisał z przymrużeniem oka, autoironicznie, np.: „moja nędzna fizjonomia”, „odpadek minionych czasów”, nigdy nie stawiał siebie na pierwszym miejscu. Wyróżniają go jedynie jego własne komentarze, oceny, refleksje, dzięki nim jest wyraźnie obecny we wspomnieniach.

Czytając Przechadzki, należy mieć na uwadze fakt, że to, co autor przekazał, i sposób, w jaki to zrobił, związane są ściśle z jego pozycją społeczną, środowiskiem, w którym się wychował, oraz światopoglądem,

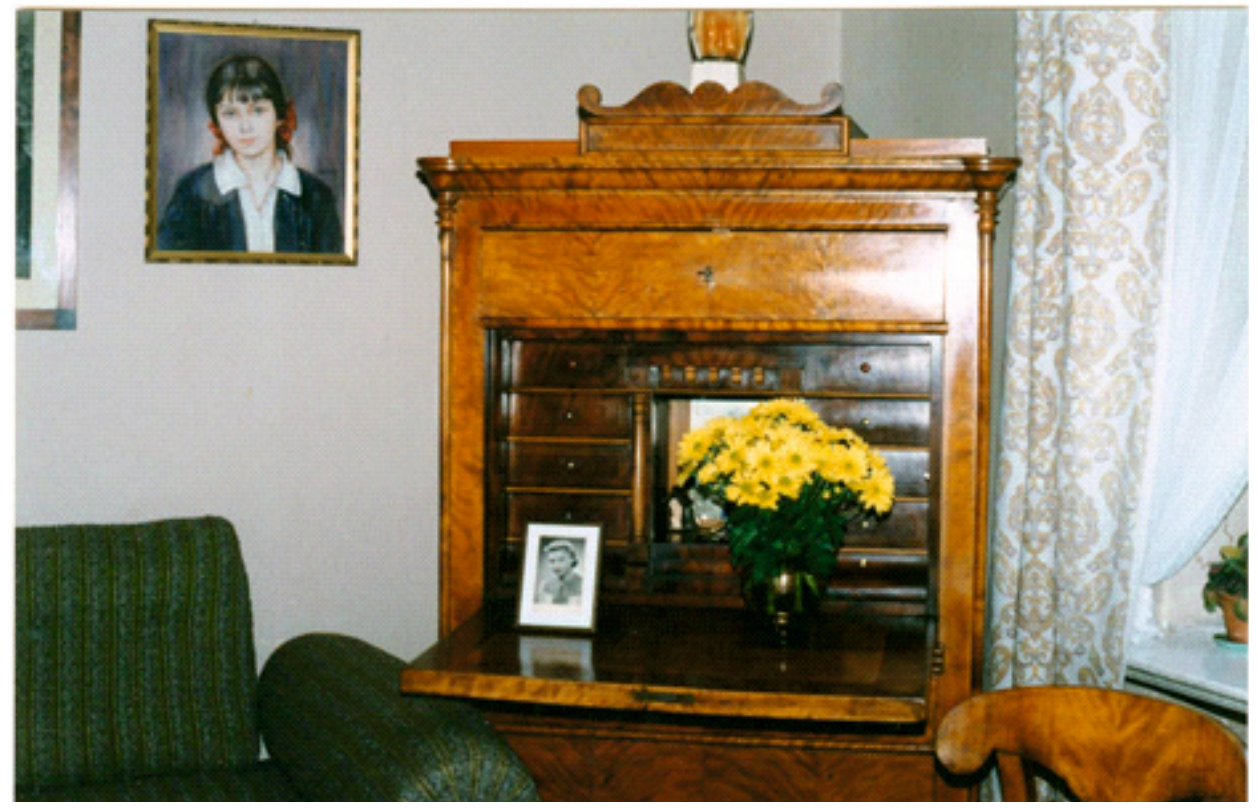

Il. 6. Sekretarzyk, na którym Motty pisał Przechadzki po mieście, obecnie w zbiorach rodziny Mottych

Źródło: zbiory autorki.

${ }^{23}$ Ibidem, s. 35. 
jaki reprezentował. Na każde bowiem dzieło nieodparty wpływ wywiera środowisko i ideały epoki. Motty był świadkiem wielu zmian w życiu społeczno-ekonomicznym, zanikania hegemonii warstwy ziemiańskiej, a wzrostu znaczenia mieszczaństwa i inteligencji. Był przedstawicielem warstwy, której znaczenie rosło, ale nie zapomniał, że stało się to za sprawą opieki i wsparcia ziemiaństwa. Zasługi, charakter i specyfikę reprezentantów tych warstw wraz z rozwijającym się mieszczaństwem zamierzał ukazać w sposób szczególny w swym dziele.

\section{Panorama biografii mieszkańców XIX-wiecznego Poznania}

Miejsca i budynki to martwe, architektów tylko zajmujące przedmioty, którym dopiero ludzie, co w nich przebywali, nadają znaczenia i wartości ${ }^{24}$.

Czołową wartością Przechadzek po mieście, a tym samym ich zasadniczą treścią jest szeroka panorama biografii. Biografii mniej lub bardziej obszernych można się w Przechadzkach doliczyć kilkuset. Niektóre z życiorysów są jedynym źródłem wiedzy o postaciach, których nikt nigdy nie upamiętnił w żadnych zapisach.

Mimo iż autor wędruje po mieście, to nie architektura zajmuje go najbardziej, lecz mieszkańcy. Dobitnie wyjaśniał przyczynę swego zainteresowania ludźmi i potrzebę uwieczniania ich w swych opowieściach: „Pragnę, żeby każdy z was, młodych, znał i cenił zacnych i rzadkich ludzi, którzy tu między nami dla dobra publicznego pracowali, a życie ich brał sobie za wzór" ${ }^{\prime 25}$. Motty, widząc w czasach sobie współczesnych zmaterializowanie społeczeństwa, chciał ukazać życie i pracę wybitnych jednostek z okresu swej młodości, dla których działalność dla dobra publicznego była niejednokrotnie sensem życia. Opisywał najczęściej tych, których znał lub często widywał. Ten krąg osób jest niewiarygodnie szeroki. Obszerność ich życiorysów zależy od stopnia znajomości, wielkości zasług oraz sympatii do nich i ich rodzin żywionej przez autora. Zdzisław Grot tak oceniał te minibiografie:

w malowaniu portretów ludzkich Motty okazał się prawdziwym mistrzem. Choć stworzył ich setki, nie tworzył stereotypowo, postacie pojawiają się w swym

\footnotetext{
${ }^{24}$ Ibidem, s. 14.

${ }^{25}$ Ibidem, s. 108.
} 
autentycznym wyglądzie tak zewnętrznym, jak i duchowym. Odmalować zewnętrzny wygląd jest rzeczą niełatwą i wymaga bystrej spostrzegawczości, a cóż dopiero przeniknąć duszę ludzką i jej różne stany, myśli i uczucia. Motty posiadał tę zdolność, a opisywał tak sugestywnie, że nie można ich sobie inaczej wyobrazić ${ }^{26}$.

\section{Przedstawiciele ziemiaństwa}

Wiele pozytywnych słów Motty skierował pod adresem rodów ziemiańskich, z którymi przyszło mu się stykać od czasów dzieciństwa, m.in. Mielżyńskich, Działyńskich. Podczas pierwszej przechadzki po terenie Starego Rynku nadarzyła się okazja, by przy pałacu właścicieli Kórnika snuć opowieść właśnie o nich. W sposób niezwykle plastyczny Motty scharakteryzował Tytusa Działyńskiego:

był ostatnim u nas panem polskim, w tym znaczeniu, jak to mówiono dawniej: panowie i szlachta; miał wszystkie przymioty i przywary swoich antenatów. Nie wyjdzie mi z pamięci twarz jego piękna i szlachetna, zwykle mocno ożywiona różnymi myślami [...], było w niej coś niepospolitego i nadzwyczaj pociągającego [...], szczególnie $w$ dziedzinie naukowej zadziwiał czasem uwagami swymi i pomysłami nawet ludzi fachowych ${ }^{27}$.

Podziwiał jego wiedzę, zdolności do języków, nieprzeciętną pamięć. Wspomniał pasję do ksiąg, rękopisów, pamiątek narodowych. Podkreślił jego udział w powstaniu listopadowym, działalność w Towarzystwie Naukowej Pomocy, wkład w powstanie PTPN-u. Nie omieszkał jednak wypomnieć także wad: zbytniej drażliwości, pobudliwości, poczucia wyższości rodowej, unikania towarzystwa. Ciepło wypowiadał się o żonie Tytusa, pani Celinie, wskazując na jej odmienny od męża charakter oraz wielkie zasługi dla Poznania. Wskazał na niezwykłą skromność tej pary i ograniczenie do minimum codziennych potrzeb, wygód, kontrastujące $z$ wielką ofiarnością na cele publiczne. Na temat ich syna Jana także nie szczędził pozytywnych słów, wymieniając wśród jego zalet m.in. szczerość, otwartość, prostotę i dobroć serca, brak dumy rodowej i pychy. Podkreślał jego wyniesiony z domu gorący patriotyzm. Marceli nie krył żalu po jego przedwczesnej, bezpotomnej śmierci jako ostatniego przedstawiciela znakomitego rodu, zadawał jednocześnie pytanie:

\footnotetext{
26 Z. Grot, Przedmowa, w: M. Motty, Listy Wojtusia...

27 M. Motty, Przechadzki..., t. 1, s. 23.
} 


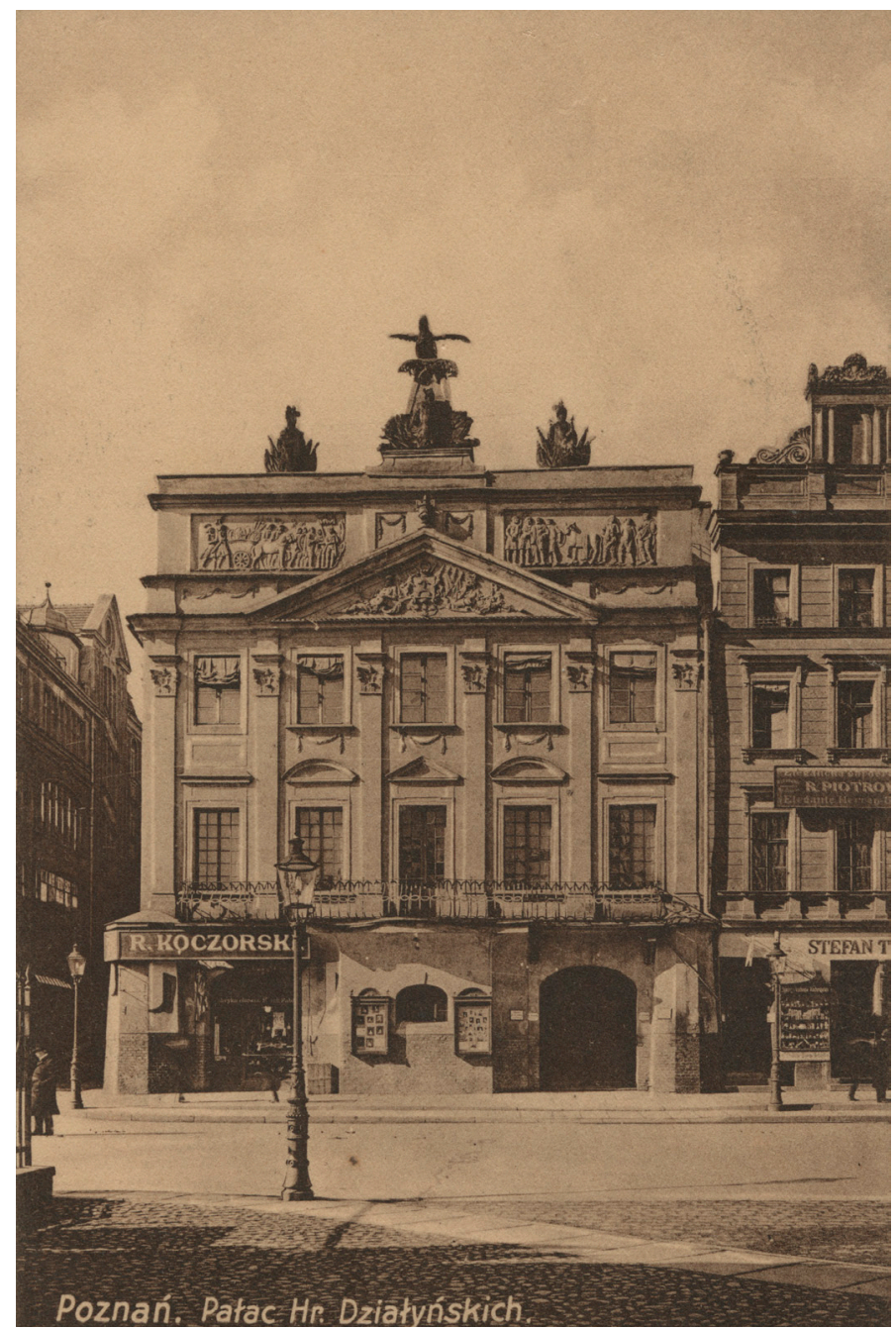

Il. 7. Pałac Działyńskich - pocztówka z około 1910 roku Źródło: zbiory Biblioteki Uniwersyteckiej w Poznaniu.

„Iluż jeszcze takich mamy na tym stanowisku?"28. Zastanawiał się, czy znajdą się tacy, którzy tę pustkę wypełnią i dla dobra narodowego tak wiele poświęcą.

Ród Mielżyńskich przybliżył Motty nie na Starym Rynku, przy pałacu będącym ich własnością do 1838 roku, lecz przy okazji spaceru wzdłuż Alei Marcinkowskiego (dawnej ul. Wilhelmowskiej), gdzie Mielżyńscy mieszkali w kamienicy. Marceli powrócił pamięcią do biografii swego ojca,

\footnotetext{
${ }^{28}$ Ibidem, s. 28.
} 
jego pobytu za młodu w majątku Mielżyńskich w Miłosławiu w charakterze guwernera oraz bardzo szczegółowo sportretował poszczególnych członków rodu z Sewerynem i Maciejem na czele. Wyróżnił zwłaszcza drugiego z wymienionych, który notabene był jego ojcem chrzestnym. Marceli wiele mu zawdzięczał, łączyła ich wspólna działalność i poglądy. Tak oto wspominał Macieja Mielżyńskiego:

Do ostatniej chwili zachował także tę zewnętrzność piękną i szlachetna, to obejście otwarte, przyjacielskie, nieraz wesołe, choć pełne godności i taktu, którym sobie wszystkich ujmował; do ostatniej chwili, dbały o innych, o samym sobie myślał jak najmniej, żyjąc od pierwszej młodości aż do zbytku skromnie i odmawiając sobie jak Marcinkowski, owych względów i wygód $[\ldots]^{29}$.

Charakterystyczne jest, że Motty często podkreślał rezygnację z przywilejów rodowych, przyjemności i wygód u przedstawicieli ziemiaństwa. Jakby pouczał usilnie czytelników, że nie dobra materialne i używanie życia w chwili, gdy ojczyzna woła o pomoc, są prawdziwą wartością, ale to, ile się uczyni dla dobra wspólnego, społecznego.

Druga przechadzka stała się pretekstem do przywołania rodu Raczyńskich. Edwarda nie znał osobiście, lecz widywał go często w Poznaniu i sporo o nim słyszał. Przeciwnicy zarzucali właścicielowi Rogalina nadmierną dumę rodową i nieprzystępność, Motty usprawiedliwiał tę skłonność, eksponując jego zasługi dla miasta w myśl francuskiego przysłowia "szlachectwo zobowiązuje”: „Nie zapominał, że jest Polakiem, a jako pan polski uważał za powinność objawiać tę pańskość na korzyść swego narodu" ${ }^{\prime 30}$. Podobnie w przypadku syna Edwarda - Rogera. Wprawdzie Motty zaznaczył, iż ten otrzymał wychowanie i wykształcenie za granicą w duchu kosmopolitycznym, jednak dalej uznał, że „patriotą był przecież gorącym i aż do śmierci zachował jak najżywsze współczucie dla spraw narodowych, gotów w każdej chwili do ofiar osobistych i majątkowych" ${ }^{31}$. Oględnie potraktował natomiast Atanazego Raczyńskiego, wypominając jego zniemczenie i „wstręt do wszystkiego, co nasze”, w przeciwieństwie do jego syna Karola, który „nauczył się po polsku i nieraz [...] okazał dla Polaków życzliwe chęci" 32 .

Motty chętnie przebywał w kręgach ziemiaństwa, dlatego zrozumiały $\mathrm{w}$ tym kontekście wydaje się fakt poślubienia jednej z przedstawicielek

\footnotetext{
${ }^{29}$ Ibidem, s. 108.

${ }^{30}$ Ibidem, s. 164.

31 Ibidem, s. 171.

${ }^{32}$ Ibidem, s. 112.
} 


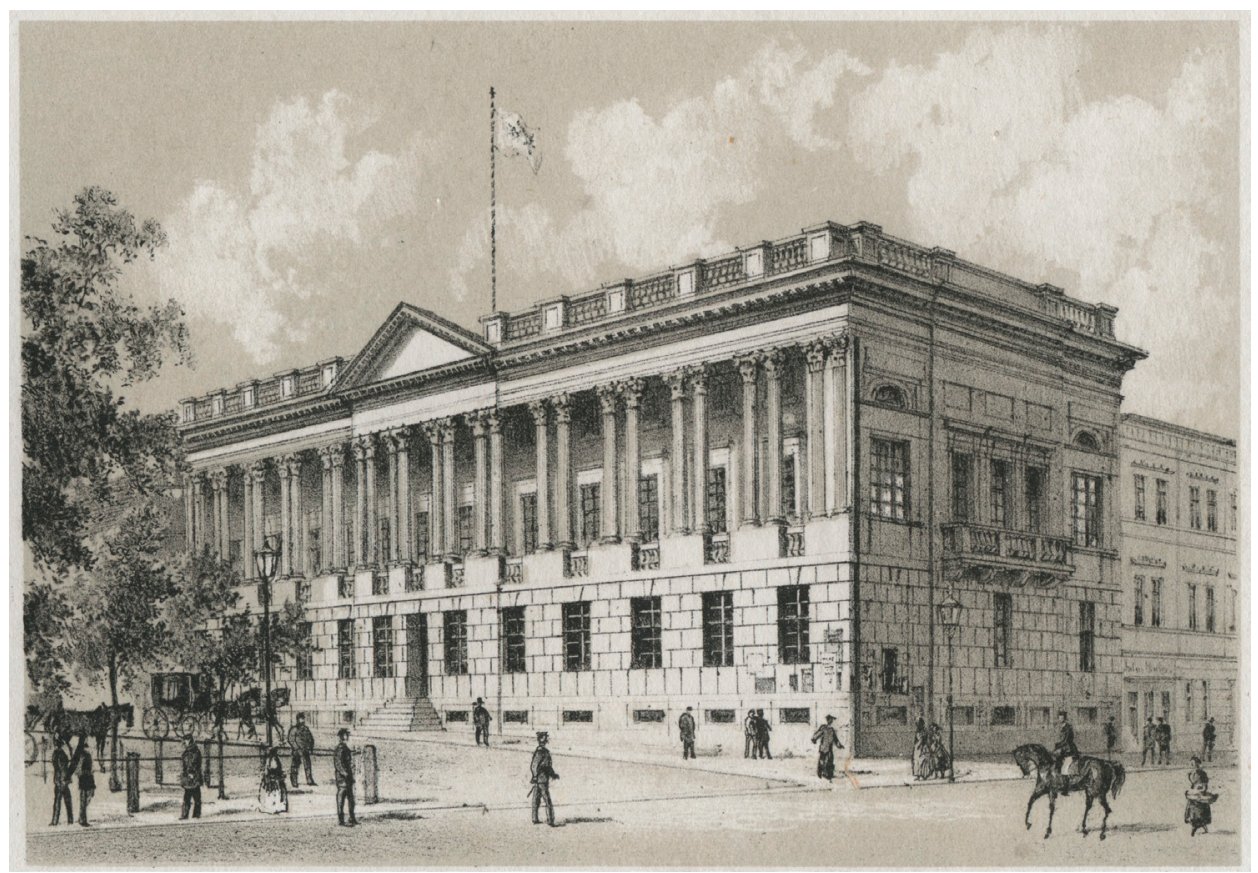

Il. 8. Biblioteka Raczyńskich - litografia R. Geisslera z około 1870 roku z Albumu miasta Poznania. 18 pamiatkowych widoków...

Źródło: zbiory Biblioteki Uniwersyteckiej w Poznaniu.

tej warstwy. Był stałym bywalcem tzw. domów otwartych (salonów literackich), gdzie zbierała się ówczesna elita intelektualna, m.in. u Jędrzeja i Bibianny Moraczewskich. Szczególnym szacunkiem darzył Bibiannę: „Była to Polka, że tak powiem najczystszej wody, w której nie znalazłeś ani źdźbła cudzoziemszczyzny w myślach, uczuciach, uczynkach i obcowaniu z ludźmi [...] władała piórem niepospolicie i przysługiwała się także pod tym względem wspólnej sprawie" ${ }^{\prime 33}$. Podkreślał jej patriotyzm i zasługi w działalności charytatywnej.

Motty przedstawił omawianą grupę społeczną w dużej mierze jako swoistych gości miasta. Ich światem bowiem nie był Poznań, lecz rozsiane na terenie Wielkiego Księstwa Poznańskiego rezydencje, majątki. Opuszczali je przy okazji swej działalności społecznej czy chociażby bali, na które tłumnie zjeżdżali do miasta w karnawale.

${ }^{33}$ Ibidem, s. 224. 


\section{Przedstawiciele inteligencji i mieszczaństwa}

Najwięcej miejsca Motty poświęcił przedstawicielom swojej warstwy, czyli inteligencji (w tym gronie znaleźli się: nauczyciele, urzędnicy, literaci, redaktorzy, duchowni, lekarze, aptekarze, artyści) ${ }^{34}$ oraz zamożnemu mieszczaństwu (kupcy, przemysłowcy, rzemieślnicy). Inteligencja polska, zwana „kwiatem narodu”, obok ziemiaństwa sprawowała "rząd dusz”, trudno się więc dziwić Marcelemu, że chciał wyeksponować jej działalność.

Uderza schemat życiorysów. Sposób charakteryzowania postaci odzwierciedla postawę ideologiczną Mottego jako organicznika. Z tego punktu widzenia wychodził, gdy oceniał działalność poszczególnych postaci. Godni pochwały według niego są ci, którzy za młodu byli w "spiskach”, potem „bronili ojczyzny w 1831 r.”, a później „zamienili szable na lemiesze i bronili ziemi". Sam autor zaznaczył, że jego głównym celem $\mathrm{w}$ charakteryzowaniu postaci jest zwrócenie uwagi na to, co „,jest w związku z przywiązaniem do rzeczy ojczystych, z poświęceniem dla wspólnej nam sprawy" ${ }^{\prime 35}$. Można stwierdzić, iż Przechadzki po mieście stanowią swoistą apoteozę czołowych organiczników XIX wieku i ich idei, na pierwszym miejscu stawiających oświatę i pracę, jedynie one bowiem mogą utorować drogę w kierunku ukształtowania się nowoczesnego społeczeństwa polskiego.

Na czoło organiczników wysuwa się lider pracy organicznej - Karol Marcinkowski. Marceli podkreślił swoje bezpośrednie kontakty z nim w kontekście zawodowym - jako lekarza rodziny Mottych, następnie społecznym - jako założyciela Towarzystwa Naukowej Pomocy, którego Motty był aktywnym członkiem, jak i prywatnym - spotkania, rozmowy, które razem odbyli tuż przed śmiercią wybitnego "Doktora Marcina”. Motty nie ukrywał osobistego żalu i wzruszenia z powodu jego przedwczesnej śmierci. Uważał Marcinkowskiego za jednostkę nieprzeciętna,

${ }^{34}$ W. Molik, Inteligencja polska w dziewiętnastowiecznym Poznaniu. Liczebność i struktura zawodowa, „Kronika Miasta Poznania” 1998, nr 2. W zaborze pruskim panowały niekorzystne warunki dla rozwoju polskiej inteligencji ze względu na dążenia do zintegrowania ziem polskich z macierzystymi prowincjami pruskimi i całkowitego zgermanizowania administracji, sądownictwa, szkolnictwa. Najliczniejszą grupę stanowili urzędnicy, drugą pod względem liczebności grupę polskiej inteligencji tworzyło w Poznaniu duchowieństwo, następnie lekarze - najmniej uzależnieni od władz, nauczyciele gimnazjalni, nieduże w omawianym okresie było jeszcze grono redaktorów prasowych, artystów, aktorów, inżynierów, aptekarzy itd. Generalnie w połowie XIX wieku inteligencja poznańska była jeszcze niewielką warstwą liczącą około 80-100 osób. Duże zasługi w jej rozwoju miało Towarzystwo Naukowej Pomocy.

${ }^{35}$ M. Motty, Przechadzki.., t. 1, s. 231. 
pełną poświęcenia dla innych, aż do zatracenia samego siebie, nad wyraz godną naśladowania. Pisał: „Przy pożegnaniu uściskaliśmy się serdecznie, a zrobiło mi się bardzo miękko, bo widziałem, że koniec z człowiekiem, a takiego długo będziem czekali [...] ile razy obok tej apteki lub obok owego domu na Podgórnej ulicy przechodzę, tyle razy pomyślę sobie: «Panie, daj nam znów takiego!» ${ }^{36}$.

Twórca Przechadzek po mieście wysoko cenił ludzi, którzy swą pozycję w społeczeństwie zawdzięczali zdolnościom, pracy i poświęceniu, a nie tych, którzy bazowali na nazwisku rodowym lub „płynęli na fali” osiągnięć swych przodków. Człowiekiem, który wiele dokonał i sam zapracował na swoje nazwisko, był kolejny przedstawiciel obozu organiczników Karol Libelt. Motty podsumował go następująco: „przez lat czterdzieści przeszło tak wybitne stanowisko zajmował w naszym społeczeństwie i [...] je na zawsze zachowa w dziejach Wielkiego Księstwa, jako też piśmiennictwa polskiego" ${ }^{\prime 3}$.

Jako w pewnym sensie biograf Hipolita Cegielskiego ${ }^{38}$ swemu szwagrowi, przyjacielowi i człowiekowi, którego wielce cenił, poświęcił bardzo dużo miejsca i sporo serdecznych, nieraz tkliwych słów. Wyeksponował przede wszystkim jego zasługi dla dobra ogólnego:

Pracę na polu usług obywatelskich, uważając za święty u nas obowiązek każdej jednostki czującej i myślącej, przy tym dla rozumu swego i pracowitości poszukiwanym będąc przy każdej sposobności przez innych, wreszcie w środki materialne statecznie wyposażony, aby zająć pewne podnioślejsze stanowisko, stał się Cegielski uczestnikiem, a bardzo często inicjatorem we wszystkim, co tylko działo się wtenczas dla dobra społeczności. Nie było towarzystwa, komitetu, wspólnego przedsięwzięcia, do którego by nie należał ${ }^{39}$.

O swym drugim bliskim przyjacielu, społeczniku Władysławie Bentkowskim mówił, że jest niejako „drugim Cegielskim”. Chciał w pamięci

\footnotetext{
${ }^{36}$ Ibidem, s. 21.

${ }^{37}$ Ibidem, s. 274.

${ }^{38}$ M. Motty, Hipolit Cegielski, „Dziennik Poznański” 1868, nr 279. Motty anonimowo zamieścił obszerne wspomnienie pośmiertne, w którym z żalem stwierdzał m.in.: „Ludzi czynu i ludzi zasługi zabiera nam jednego po drugim los nienawistny, nim którykolwiek z nich dojdzie do podeszłego wieku, nim wypełnić zdoła wszystko, co dla dobra publicznego zamierzał i chował w głębi ducha swego [...]. Panie, zabrałeś nam znów jednego z owych przywódców, którzy stawali za nas, którzy byli dla nas jasnym kagańcem wśród ciemności, obojętnych budzili, zwątpiałym dodawali otuchy i pracowali za wszystkich!".
}

${ }^{39}$ M. Motty, Przechadzki.., t. 1, s. 397. 
potomnych utrwalić tę postać z jej niezwykle bogatym życiorysem. Bentkowski potrafił, gdy zaszła potrzeba, z wojskowego i polityka przedzierzgnąc się w redaktora "Gońca Polskiego", potem kupca i fabrykanta, a także opiekuna osieroconych dzieci Hipolita Cegielskiego:

Pracując od rana do nocy, czuwając bez przestanku nad domem i zakładem fabrycznym, nie pomijając żadnej drobnostki, oceniając jasno co być powinno, a co nie, ziścił zupełnie nadzieje zmarłego przyjaciela. Syna wychował tak, iż jak ci wiadomo, godnym stara się okazać ojca swego i opiekuna; córkę młodszą starannie wypielęgnowana, wydał za człowieka zajmującego zaszczytne stanowisko w społeczeństwie polskim; majątek powierzonej sobie rodziny zabezpieczył i powiększył, a fabrykę udoskonalił i rozszerzył [...], wypełniając z pedantyczną sumiennością wszystkie te obowiązki [...], nie spuszczał z oka spraw publicznych i ile mógł, gorliwie się nimi zajmował ${ }^{40}$.

Przy okazji snucia opowieści o Gustawie Potworowskim kolejny raz skupił uwagę pana Ludwika na zasługach opisywanej postaci dla sprawy narodowej: „czym był niezwyczajny? Otóż sercem, sercem dla sprawy narodowej, sercem dla współziomków. Wszędzie, gdzie szło o rzecz publiczna, o wspólne dobro nasze [...], zawsze był gotów, a przykładem i wpływem pociągał innych za sobą" ${ }^{41}$.

Założenia innych obozów są dla Mottego "niewczesnymi porywami”, „różowymi na świat zapatrywaniami”. Nie wyraził wprawdzie ostro swego krytycznego stosunku do obozu demokratycznego, ale wyczuwa się w jego wypowiedzi niechęć do jego zwolenników, zwłaszcza najbardziej radykalnych. Edwarda Dembowskiego postrzegał jeszcze dość życzliwie, natomiast nie akceptował Walentego Stefańskiego ze względu na podejrzenia o nieuczciwe machinacje. W ocenie Antoniego i Julii Woykowskich o sympatiach w kierunku socjalizmu utopijnego pisał oględnie, pouczając młode pokolenie: „smutny koniec Antosia Woykowskiego stwierdza tę bardzo oklepaną prawdę, o której jednak młodzież nasza zapomina aż nadto często, że kto chce się jako tako przez ten świat nieszczególny przerąbać, musi mieć rozum w głowie i statek w życiu" ${ }^{\prime 2}$.

Wśród przedstawicieli inteligencji Motty nie omieszkał zamieścić biografii swych szkolnych profesorów, z ich zasługami, a niekiedy i wadami, śmiesznostkami. Podkreślał ich dokonania na polu dydaktycznym, naukowym, a także publicystycznym. Sporo miejsca poświęcił też poznańskim

\footnotetext{
${ }^{40}$ Ibidem, s. $416-417$.

41 Ibidem, s. 239.

${ }^{42}$ Ibidem, s. 51.
} 
szkołom, w tym Gimnazjum św. Marii Magdaleny czy szkole żeńskiej Tekli Herwigowej. Przy okazji problematyki szkolnictwa i oświaty pojawiają się też postaci kobiet - wychowawczyń, nauczycielek zasłużonych na gruncie narodowym i dydaktycznym (Anna i Anastazja Danyszówny, Anastazja Warnke i inne).

W kręgu zainteresowań Mottego znaleźli się księgarze i wydawcy, z Janem Konstantym Żupańskim na czele, którego pracę Motty szczególnie poważał:

Od samego początku postanowił nie poprzestać na zwyczajnym sortymentowym handlu, lecz przyczynić się jako wydawca do wspierania sprawy narodowej w jednym z najważniejszych jej kierunków i zadanie to wypełnił w takiej mierze, $\mathrm{w}$ jakiej żaden wydawca polski przed nim $[\ldots]^{43}$.

Nie zapomniał o dokonaniach poznańskich historyków - Jędrzeja Moraczewskiego, Józefa Łukaszewicza ${ }^{44}$, Kazimierza Jarochowskiego którzy swe zainteresowania badawcze poświęcili dziejom Polski, Wielkopolski, Poznania. O ostatnim z wymienionych wyraził się tymi słowy: „człowiek niepospolitej siły i sprężystości umysłowej [...]. Kto go znał bliżej, musiał w nim podziwiać rzadkie, niestety u nas przymioty: zamiłowanie i wytrwałość w pracy, a obok tego szybkość w myśleniu i łatwość w pisaniu" ${ }^{\prime 4}$. Motty, choć zaznacza, iż nie czuje się bibliografem czy recenzentem, podobnie jak w Listach Wojtusia i teraz poleca towarzyszowi swej przechadzki przeczytanie dzieł przywoływanych uczonych.

Grupą zawodową która odegrała znaczną rolę w życiu miasta, byli prawnicy. Wśród nich Motty wymienił m.in. Jakuba Krauthofera-Krotowskiego, jedną z czołowych postaci Wiosny Ludów, który „obok prac urzędowych zajmował się gorliwie wszystkim co tylko ze sprawą narodową jakikolwiek miało związek"46, i jego przyjaciela Władysława Niegolewskiego - wielokrotnego posła na sejm pruski i parlamentu Rzeszy.

Nie uszli uwadze Mottego również reprezentanci środowiska lekarskiego. Niektórzy z nich skupieni wokół Karola Marcinkowskiego wzorem mistrza przodowali w swym zawodzie i nadawali ton życiu publicznemu miasta. O ich znaczeniu decydował profesjonalizm. Do szczególnie

${ }^{43}$ Ibidem, s. 63.

${ }^{44}$ M. Motty, Józef Łukaszewicz, „Dziennik Poznański” 1873, nr 184, 185. Motty zamieścił anonimowo wspomnienie pośmiertne, którym zaprzeczył słowom Łukaszewicza, jakoby po śmierci nikt o nim pisać nie będzie.

${ }^{45}$ M. Motty, Przechadzki..., t. 1, s. 119-120.

46 Ibidem, s. 307. 
zasłużonych w zawodzie należeli: Antoni Jagielski, Teofil Matecki, Ludwik Gąsiorowski. Najserdeczniej wypowiadał się Motty o Mateckim: "od wieków [był - I.W.] przyjacielem moim i opiekunem cielesnym"47. Podkreślał jego fachowość, bezinteresowność - na podobieństwo Marcinkowskiego, otwartość i gościnność jego domu, a także działalność dobroczynną jego małżonki - Apolonii.

Jako miłośnik teatru, podobnie jak w cyklu De omnibus rebus..., zamieścił omówienie osiągnięć artystów scen zawodowych (krakowskich i warszawskich od czasów Bogusławskiego), ale zaznaczył: „o dziejach [...] zakulisowych niewiele, panie Ludwiku, dowiesz się ode mnie" ${ }^{48}$. Nie uznał za stosowne uwiecznić szczególnie obszernymi biografiami synów i córek Melpomeny. Prześledził rozwój form teatru omawianej epoki od przedstawień na jarmarkach, po przedstawienia trup cudzoziemskich, gdzie prócz La donna e mobile można było zobaczyć występy o charakterze cyrkowym. Przy okazji Motty dorzucił kilka słów o widowni. Opisał również sztuki amatorskie organizowane na cele dobroczynne. Swój udział jako reżysera $\mathrm{w}$ ich realizacji (m.in. w 1845 roku z inicjatywy Towarzystwa Dobroczynności) nazwał „skromnymi obowiązkami zakulisowymi". Zaskakująco mało uwagi poświęcił swej ulubionej aktorce Helenie Modrzejewskiej, na której cześć pisał niegdyś peany. Uznał natomiast, że wielkość aktorki odkryli dopiero poznaniacy. Od Poznania - jak twierdził - zaczęła się światowa kariera Modrzejewskiej ${ }^{49}$.

W Przechadzkach mają swe miejsce także reprezentanci sztuk pięknych, m.in: Fabian Sarnecki, Oskar Sosnowski, Władysław Oleszczyński, Teofil Mielcarzewicz, Edward Gillern. Potraktowani zostali przez autora dość ogólnikowo, zasadniczo w kontekście swych realizacji artystycznych.

Motty obszernie wypowiedział się o czasach urzędowania w Poznaniu namiestnikostwa Radziwiłłów, gdy miasto stało się widownią wielu wydarzeń kulturalnych - koncertów, bali, przyjęć. Rodzina Mottych z racji swych związków z dworem w wielu z nich uczestniczyła ${ }^{50}$.

Część inteligencji polskiej w Poznaniu stanowiło duchowieństwo mające duże możliwości oddziaływania na społeczeństwo ze względu na tradycję i bezpośredni kontakt z wiernymi. Poza tym ważny jest fakt, że zdecydowana większość kleru była pochodzenia polskiego, a zaborca

47 Ibidem, s. 318.

48 Ibidem, s. 195.

49 A.W., Na fali wspomnień, „Teatr i Film” 1958, nr 1, s. 30.

${ }^{50}$ Marceli już jako mały chłopiec bywał na łzw. kinderbalikach organizowanych dla dzieci z wyższych sfer na dworze Radziwiłłów z okazji urodzin księżniczki Wandy. 
zdawał sobie sprawę z roli, jaką odgrywał on w obronie polskości ${ }^{51}$. Marceli Motty, nie omawiając Ostrowa Tumskiego, nie zaprezentował też jego mieszkańców - arcybiskupów i biskupów. Siedziba arcypasterza miała wszak wymiar symboliczny. Społeczeństwo w dobie zaborów widziało w nim swego przywódcę i ceniło za moralną postawę. Nieuwzględnienie wyższego duchowieństwa w Przechadzkach stanowi więc dużą lukę w galerii prezentowanych postaci. Pojawiły się natomiast sylwetki księży, którzy włączyli się w realizację programu prac organicznych. Pionierem był ks. Józef Brzeziński, najbliższy współpracownik Karola Marcinkowskiego, jeden z najwybitniejszych działaczy Towarzystwa Naukowej Pomocy. W samych Przechadzkach jest przywoływany przy okazji omawiania m.in. działalności Towarzystwa Naukowej Pomocy. Być może opublikowana biografia Brzezińskiego ${ }^{52}$ (obejmująca 38 stron) w 1878 roku, nakładem Józefa Ignacego Kraszewskiego, sprawiła, iż Motty ograniczył się we wspomnieniach przechadzkowych do podstawowych, niezbędnych informacji o księdzu, zakładając, że postać jest wystarczająco znana mieszkańcom Poznania.

W dyrekcji Towarzystwa Naukowej Pomocy zasiadał także ks. Aleksy Prusinowski, Motty wyróżnił go w swej opowieści jako wybitnego, niemającego sobie równych kaznodzieję. Niektóre z jego wystąpień czy homilii zostały ogłoszone drukiem, m.in. mowy żałobne na nabożeństwach za Adama Mickiewicza, Joachima Lelewela, Adama Czartoryskiego i innych znanych postaci. Motty podkreślił bogatą działalność publicystyczną kapłana, od współpracy z "Gazetą Polską" począwszy. Bliski był mu również ze względu na pracę w szkole żeńskiej Tekli Herwig - babki Marcelego. Rozpisawszy się nieco na temat Prusinowskiego, Motty podsumował swe rozważanie następująco: „dwoma słowy zbyć nie mogłem człowieka tej wartości [...] i niezmordowanej pracy na polu kościelnym i narodowym" ${ }^{53}$. Dla Mottego kolejnym duchownym, którego nie mógł pominąć podczas spaceru po Wzgórzu św. Wojciecha, był prężny proboszcz tutejszej parafii - ks. Franciszek Bażyński.

${ }^{51}$ L. Trzeciakowski, op.cit., s. 42; księża, z którymi Motty miał styczność w gimnazjum na lekcjach religii, uwzględnieni zostali w Przechadzkach po mieście w ramach wspomnień o Gimnazjum św. Marii Magdaleny (m.in. bohater powstania listopadowego - ks. Adam Loga).

${ }^{52}$ M. Motty, Wspomnienie..., s. 38: „najchętniej rozprawiał i myślał o rzeczach ojczystych, o tym co nas boli, co nam szkodzi, co pomóc może i co nam potrzeba, bo do szpiku kości był Polakiem i naród swój kochał nad wszystko. Cała niemal praca jego życia [...] zmierzała ku ocaleniu i ustaleniu bytu narodowego, a każde rozsądne żądanie w imię publicznego dobra znalazło go zawsze gotowym".

${ }^{53}$ M. Motty, Przechadzki..., t. 2, s. 212-213. 
Za szczególne zasługi Motty poczytywał mu założenie czytelni polskiej dla księży, wydawanie obrazków świętych z polskimi napisami i modlitewników, utworzenie w Poznaniu Wydawnictwa Dobrych a Tanich Książek dla Ludu. Pisał:

Myśl narodowa była dla Bażyńskiego wszędzie i zawsze rzeczą świętą. [...] dobrodziejstwem jest dla nas nieocenionym i jedyną z najsilniejszych dźwigni tak srodze zagrożonej narodowości wszystko, co oświatę, moralność, poczucie polskości, wspomnienia przeszłości pomiędzy ludem wsi i miasteczek rozszerza i rozbudza ${ }^{54}$.

Za odwagę w szerzeniu oświaty wdzięczna inteligencja polska podarowała ks. Bażyńskiemu z okazji jubileuszu 50-lecia kapłaństwa księgę pamiątkową zatytułowaną Warta, zawierającą "prócz objawów na cześć jubilata" artykuły o treści religijnej, historycznej, napisane przez około 40 literatów z różnych stron Polski, w tym Marcelego Mottego esej Ludwik IX - wizerunek historyczny ${ }^{55}$.

Wiele miejsca Motty poświęcił rosnącemu w siłę zamożnemu mieszczaństwu, zwracając uwagę na sposoby osiągania przez jej przedstawicieli sukcesów i rozwijania kariery zawodowej. Na kartach wspomnień uwiecznił więc cały szereg kupców, rzemieślników, przemysłowców, popierając bogacenie się żywiołu polskiego, cenił pracowitość, oszczędność, gospodarność, zaradność. W pobliżu Bazaru nie omieszkał zasygnalizować zmagań z kapitalistyczną konkurencją pierwszych tutejszych kupców, a swoich szkolnych kolegów: Feliksa Gliszczyńskiego i Marcelego Kamieńskiego. Na ich i innych przykładach pokazywał zmienność Pani Fortuny. Mimo nie najlepszej kondycji polskiego handlu, w tym zakresie palmę pierwszeństwa dzierżyli bowiem Niemcy i Żydzi, zdarzały się przypadki większych polskich karier, m.in. kupca winnego - Stanisława Powelskiego.

Z grona „rzemieślniczej arystokracji” w Przechadzkach pojawiła się spolszczona rodzina Leitgeberów, której antenat - Antoni - zapisał się jako mistrz kowalski. Motty, przedstawiając jego losy, podkreślał biegłość w obranym fachu, szybkość, dokładność, które zjednały mu przychylność i zlecenia także od władz pruskich. Dla Marcelego wielką

${ }^{54}$ Ibidem, t. 1, s. 155-156.

${ }^{55}$ M. Motty, Ludwik IX - wizerunek historyczny, w: Warta. Książka zbiorowa ofiarowana księdzu Franciszkowi Bażyńskiemu, proboszczowi przy kościele św. Wojciecha w Poznaniu, na jubileusz 50-letniego kapłaństwa w dniu 23 kwietnia 1874 od jego przyjaciót i wielbicieli, Poznań 1874. 
zasługą Antoniego był fakt, że sam sobie wszystko zawdzięczał, ciężką pracą osiągnął sukces, majątek i szacunek społeczny ${ }^{56}$. Wśród cukierników na czoło wysunął się Antoni Pfitzner, którego Marceli uważał za jednego z "najpopularniejszych mieszczan polskich w Poznaniu" 57 . Dzięki swej pracowitości i jakości wyrobów zyskał szczególne uznanie, zwłaszcza u młodszej części mieszkańców miasta. Autor Przechadzek po mieście tak wyjaśniał jego pomyślność: „Główną przyczyną czemu wszystko szło dobrze był sam pan Antoni. Zdrowy rozum i łatwą pojętność łączył z obrotnością i przedsiębiorczą fantazją która się niejednym zawodem, niejedną dotkliwą strata, jak to bywa w interesach i rzeczach pieniężnych, osłabić nie dała" 58 . Pierwszym polskim mistrzem stolarskim, fabrykantem, którego meble zostały docenione $\mathrm{w}$ kręgach ziemiańskich i za granica, był Józef Zeyland. Na sukces zdaniem Mottego zapracował sobie gruntowną znajomością rzeczy, rozsądnym dozorem, podążaniem $\mathrm{z}$ duchem czasu, przezornością $\mathrm{w}$ stosunkach finansowych, porządkiem i oszczędnością w życiu prywatnym, a także uprzejmością i skromnością. Te przymioty zjednały mu społeczną sympatię. Motty, eksponując je, dawał niejako czytelnikom receptę, jaki winien być dobry przemysłowiec kapitalista, a przy tym z radością uświadamiał, że prężne jednostki dobrze wróżą przyszłemu rozwojowi polskich inicjatyw społeczno-gospodarczych ${ }^{59}$.

\section{Mieszkańcy pochodzenia niemieckiego i żydowskiego}

Obraz społeczeństwa XIX-wiecznego Poznania byłby niepełny, gdyby zabrakło w nim wspomnienia współegzystujących ze sobą żywiołów niemieckiego i żydowskiego. Przychylny lub nieprzychylny stosunek Niemców do Polaków decyduje o dodatnim lub ujemnym tonie charakterystyki. Dla Mottego istotnym czynnikiem wartościującym jest znajomość języka polskiego, wielokrotnie od tego rozpoczyna się prezentacja postaci (np. podczas omawiania burmistrzów Karla Behma, Eugena Naumanna, Hermana Kohleisa). Na kartach Przechadzek pojawiają się m.in. niemieccy urzędnicy, radcy szkolni, dyrektorzy i nauczyciele gimnazjalni, profesorowie uniwersyteccy (z Berlina), prawnicy, kupcy, przemysłowcy, przedsiębiorcy, wojskowi. Motty

\footnotetext{
${ }^{56}$ M. Motty, Przechadzki..., t. 2, s. 274-275.

57 Ibidem, s. 55.

58 Ibidem, s. 53.

${ }^{59}$ Ibidem, s. 322-323.
} 
pozytywnie odbierał tych Niemców, którzy starali się współpracować $\mathrm{z}$ Polakami, traktując ich obiektywnie w relacjach prywatnych bądź zawodowych (m.in. Kaulfuss, Brettner, Brennecke), czym zresztą narażali się u współziomków:

jenerał Colomb [...] do Polaków nie miał żadnej nienawiści, a choć rzadko się z nimi spotykał, okazywał im przy każdej sposobności pewne współczucie, dlatego Niemcy nie bardzo go lubili. Brat Colomba [...] żył z Polakami w ścisłych stosunkach towarzyskich, tak iż syn jego, którego dobrze znałem, zupełnie się spolszczył i za Polaka uważał ${ }^{60}$.

Marceli, pisząc o wybitnych Polakach, jak Marcinkowski czy Cegielski, podkreślał, że cieszyli się szacunkiem także społeczności niemieckiej. Traktował to jako rzadkość i szczególne wyróżnienie. W biografiach niemieckich mieszkańców stolicy Wielkiego Księstwa w wielu przypadkach odczuwalna jest ironia, m.in. w odniesieniu do radcy rejencyjnego Tittla, który podobno, przeglądając się często w lustrze, zwykł wykrzykiwać: „O Tittlu, gdybyś był o stopę wyższym, byłbyś podziwem świata”61.

Motty przypomniał, że w pierwszej połowie XIX wieku nie było jeszcze takich antagonizmów między narodowościami, przywoływał wiele przypadków małżeństw mieszanych, wspólne inicjatywy polsko-niemieckie, chociażby założoną Szkołę Realna, i przy tej okazji pozytywny gest Gothilfa Bergera - sfinansowanie nowego gmachu szkoły „dla wszystkich narodowości i wyznań bez różnicy". Podsumowując wspólną uroczystość w Bazarze, napisał: „wtenczas nie była jeszcze mowa polska zgrozą dla uszu germańskich" 62 .

Autor Przechadzek trafnie ocenił sytuację wielu zakładów poznańskich: „stało się tutaj co się z wszelkimi zakładami zwykle dzieje;

${ }^{60}$ Ibidem, t. 1, s. 94.

${ }^{61}$ Ibidem, s. 33.

${ }^{62}$ Ibidem, s. 85; W.D. Engeldinger, Niemiecka inteligencja w Poznaniu w latach 1871-1914, „Kronika Miasta Poznania” 1998, nr 2. Odzwierciedleniem stosunków polsko-niemieckich byli kolejni nadburmistrzowie miasta Poznania, ich światopogląd, podejście do pełnionej funkcji, do Polaków i ich języka. Po 1870 roku obserwuje się stopniowe pogorszenie kontaktów, narasta narodowa rywalizacja. Wszystkich wyższych urzędników niemieckich obowiązywał w myśl polityki germanizacyjnej zakaz bliskich, prywatnych kontaktów z ludnością polską. Engeldinger wyróżnia trzy typy niemieckich inteligentów: nacjonaliści zaangażowani $\mathrm{w}$ akcję germanizacyjną; kosmopolici lub bezstronni (mniejszość), którzy chcąc żyć w zgodzie z Polakami, protestowali przeciwko antypolskiej działalności władz; Niemcy pochodzenia żydowskiego - stali pomiędzy rywalizującymi narodami i dążyli do społecznego uznania swojej grupy narodowościowej. 
założy Polak lub Niemiec, a Żyd potem zagarnie i zysk wyciągnie" ${ }^{\prime 63}$. Motty nie wykazywał zbytniego sentymentu dla mieszkańców Poznania narodowości żydowskiej ${ }^{64}$. Z przymrużeniem oka pisał o nadawaniu Żydom nazwisk, często zabawnych, zgodnie z nakazem władz pruskich: "Ja sam w bliskości Mławy widziałem Malowaną Szafę chodzącą na dwóch nogach obok Nowej Szklanki z pejsami i jarmułką na głowie” ${ }^{65}$. O znajomym Żydzie nazwiskiem Płachta pisał: „Pod względem narodowym ani Żyd, ani Niemiec, chciał uchodzić za Polaka, lecz był to raczej Europejczyk, czyli beznarodowiec, jak znaczna liczba wykształceńczych Żydów" ${ }^{\prime 66}$. Zarzucał Żydom poczucie wyższości rasy, solidaryzowanie z Niemcami, okazywanie niechęci Polakom. Dlatego wspominając fotografa Engelmanna, nie ukrywał zaskoczenia: „chociaż Żyd, był poczciwym chłopcem; był wesoły, szczery i przyjacielski, przy tym niezwykle czułego usposobienia [...]"67. Mile zaskoczony był też Motty, gdy podczas wesela żydowskiego w Bazarze zaobserwował, że rozmawiano po polsku. Wówczas był tylko świadkiem, nie gościem na uroczystości. Zaproszono go natomiast na wesele w Hotelu Saskim, z którego zdał relację, opisując „izraelski rytuał”. Przedstawił zdarzenie w sposób obiektywny i zaznaczył, że był to fakt wyjątkowy: „[to wesele żydowskie - I.W.] było jedyne, które w dość długim moim życiu widziałem" ${ }^{\prime 68}$. Motty pozytywnie odbierał postacie księgarza i bibliotekarza Juliusa Adolfa Munka czy antykwariusza Josepha Lissnera. Za sprawą swego ojca pozostawał z nimi w dobrych relacjach. O pierwszym pisał: „wzbogaciwszy się wśród Polaków i z Polaków, nigdy nieprzyjaźnie przeciw nim nie występował, co między Żydami naszymi rzadkim jest zjawiskiem"69, o Lissnerze natomiast: „praca, mozołem i zręcznościa, doszedł, do czego chciał [...] jak większa część bogatych Żydów u nas, był kowalem swego losu"70. Jak twierdzi Sophia Kemlein, Żydzi uchodzili za wzór jedynie na polu pomocy dla ubogich, jednakże

${ }^{63}$ M. Motty, Przechadzki..., t. 1, s. 143.

${ }^{64}$ S. Kemlein, Żydzi w Wielkim Księstwie Poznańskim 1815-1848, Poznań 2001, s. 15, po lekturze Przechadzek po mieście stwierdza, że Motty „nie kryje się ze swymi uprzedzeniami wobec Żydów”. Można to skonstatować, iż nie darzył ich jakąś szczególną sympatia, ale sądzę, że nie był do nich uprzedzony. Nastawienie Mottego było zresztą wynikiem ogólnej aury panującej wówczas wokół ludności żydowskiej.

${ }^{65}$ M. Motty, Przechadzki..., t. 2, s. 65.

${ }^{66}$ Ibidem.

${ }^{67}$ Ibidem, t. 1, s. 144.

68 Ibidem, t. 2, s. 46.

${ }^{69}$ Ibidem, t. 1, s. 32.

${ }^{70}$ Ibidem, s. 212-213. 
poza względnymi kontaktami towarzyskimi o zbliżeniach między Polakami a Żydami na płaszczyźnie politycznej, gospodarczej czy kulturalnej w ramach działalności instytucjonalnej nie było mowy. Zapewne negatywnym aspektem, dla Mottego i jemu współczesnych, była akulturacja Żydów w zakresie języka i kultury niemieckiej. To zjawisko autor Przechadzek najlepiej uwypuklił na przykładzie Roberta Remaka, który pierwotnie uchodził za całkowicie spolszczonego, nawet "sam się Polakiem mianował”, ale „patriotyzm polski wkrótce u niego uległ $\mathrm{w}$ walce $\mathrm{z}$ mamoną [...], ożeniwszy się i wyszedłwszy na profesora, zerwał wszelkie stosunki z Polakami, przedzierzgnął się w czystej krwi Germana $[\ldots]^{\prime \prime 71}$.

Motty nie zapomniał także o reprezentantach pozostałych żyjących w mieście narodowości. Przede wszystkim o grupie Francuzów, którzy utrzymywali stałe kontakty z jego ojcem (Etienne Trimail, Franciszek Julian Oudot, Douchy, François Didelot), Szwajcarów (bracia Vassali czy Possard) i innych. Przy okazji stwierdził: „Teraz nie znalazłbyś w Poznaniu Francuza na lekarstwo"72.

Jak już wspomniano, Motty nie zajmuje się w swym dziele niższymi warstwami społecznymi, biedotą miejską, proletariatem. Nie opisuje w związku z tym warunków życia tych warstw. O ich istnieniu czytelnik dowiaduje się głównie $z$ informacji o akcjach dobroczynnych tzw. naszych pań lub z relacji dotyczącej przekupek z Nowego Rynku (obecnie pl. Kolegiacki). Wydaje się, że Motty nasycił czytelnika tą problematyką w Listach Wojtusia, gdzie jako fikcyjny Wojtuś mieszkający na Zawadach zobowiązany był do komentowania swych sąsiadów. Teraz jako emerytowany profesor, jawnie występujący jako autor Przechadzek, posiadający określoną pozycję społeczną być może nie widział powodu, by w swych wspomnieniach opisywać warstwy społeczne, których przywołanie zaburzyłoby przyjętą przez niego koncepcję, w myśl której koncentrował się na jednostkach znaczących, wyróżniających się pod wieloma względami w społeczeństwie. Tacy mogli być jedynie przedstawiciele warstw oświeconych.

${ }^{71}$ Ibidem, s. 43. S. Kemlein, Między tradycja a nowoczesnościa - intelektualiści żydowscy w Poznaniu w pierwszej połowie XIX wieku, „Kronika Miasta Poznania” 1998, nr 2, s. 86, zaprzecza, jakoby Remak był spolonizowany, w jego rodzinnym domu bowiem mówiono po niemiecku. Poza tym podkreśla, że nie uważał się ani za Polaka, ani za Niemca, lecz za Żyda, naukowca i liberała, dążył do równych praw na polu naukowym.

${ }^{72}$ M. Motty, Przechadzki..., t. 1, s. 34. 


\section{Obraz miasta Poznania w Przechadzkach po mieście}

Czytelnik doszukujący się w Przechadzkach znamion przewodnika dla zwiedzających Poznań, w dzisiejszym tego słowa rozumieniu, byłby zaskoczony, bowiem Motty wprawdzie odtworzył dzieje wielu budowli, placów, ulic, opisywał ich dawny wygląd, lecz nie interesował się zupełnie architektura pod kątem estetycznym czy stylistycznym. O wyposażeniu kościoła św. Marcina wypowiedział się lakonicznie, bez jakiejkolwiek próby uściślenia pod względem artystycznym: „administracja [...] zaopatrzyła go w odpowiednie organy [...], przybudowano piękną i obszerną kaplicę $[\ldots]$, prezbiterium przyozdobiono bardzo pięknymi malowanymi oknami, w stosownych zaś miejscach umieszczono rzeźby i obrazy [... $]^{\prime 73}$.

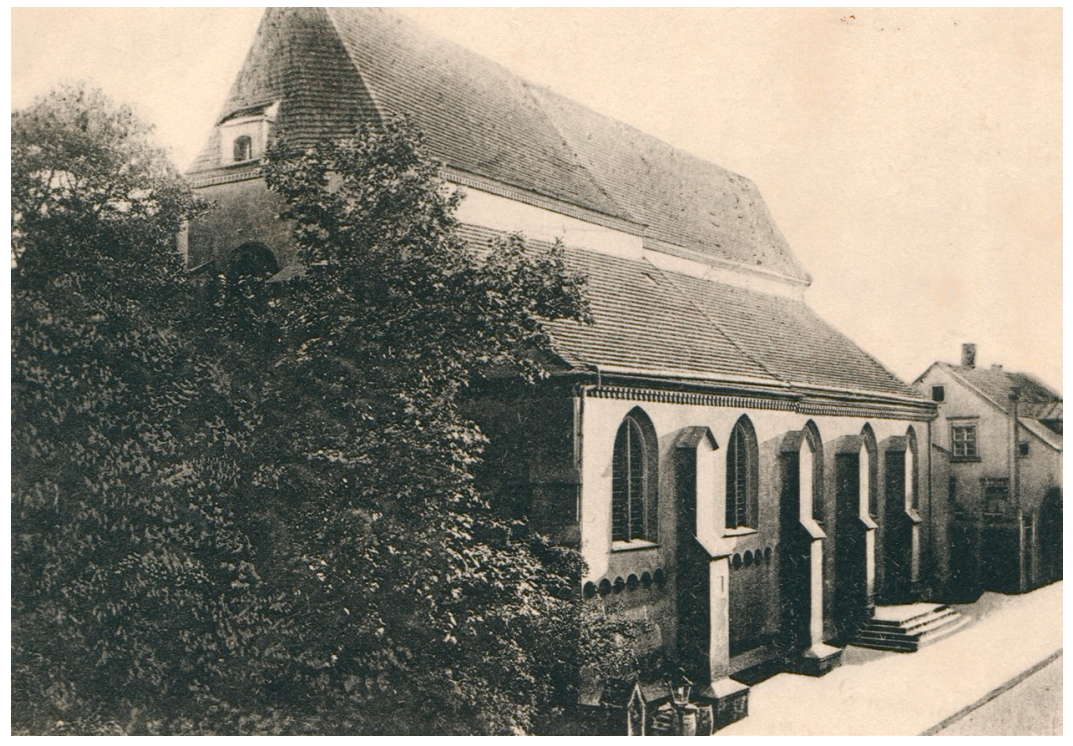

Il. 9. Kościół św. Marcina - pocztówka z około 1900 roku Źródło: zbiory Biblioteki Uniwersyteckiej w Poznaniu.

Nie poruszyło Mottego piękno renesansowego ratusza poznańskiego. Pałac Działyńskich prócz określenia „niekształtny, lecz poważny"74 nie doczekał się bardziej wyczerpującego komentarza. Jednym słowem, Motty nie przejawiał większego zainteresowania zabytkami architektury. Być może nie czuł się dostatecznie przygotowany do fachowego ich omówienia. Bardziej, jak się zdaje, odnosił się do walorów praktycznych

\footnotetext{
${ }^{73}$ Ibidem, s. 337.

${ }^{74}$ Ibidem, s. 23.
} 
zabudowy, o Rynku pisał: „w kilku miejscach połączono dwa domy w jeden, bo dawniejsza domów struktura nie odpowiednia teraźniejszym potrzebom obliczoną była na inne stosunki"75. Starał się konfrontować widoki poszczególnych części miasta ze stanem sprzed lat.

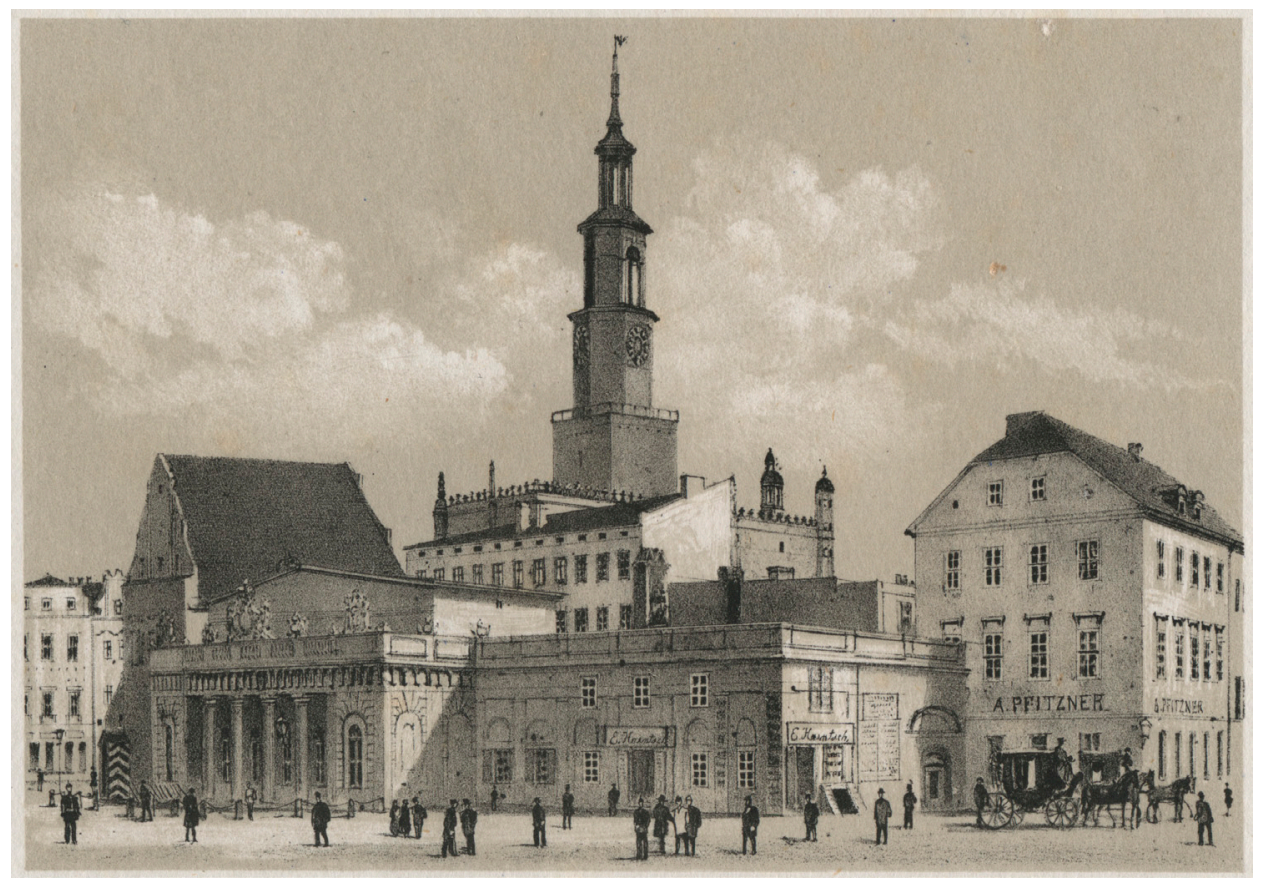

Il. 10. Stary Rynek - litografia R. Geisslera z około 1870 roku z Albumu miasta Poznania. 18 pamiątkowych widoków...

Źródło: zbiory Biblioteki Uniwersyteckiej w Poznaniu.

Tak pisał o pl. Królewskim (obecnie pl. Cyryla Ratajskiego) na podstawie reliktów swej pamięci: „około trzydziestego roku i jeszcze lat kilka później całkiem inaczej wyglądało niż teraz. Pamiętam tu same puste miejsca i płoty, wśród których stały ledwo dwa, trzy murowane domy"76.

Widoki Poznania malują się przed oczami odbiorców gawędy Mottego niczym rysunki Juliusa von Minutoliego. Mają nad nimi przewagę w postaci transformacji w czasie. Motty nie jest „nowoczesny” w tym sensie, iż nie skupia się na osiągnięciach technicznych, np. kolei, wodociągach. Zresztą trudno wymagać tego od filologa, który chciał przekazać obraz miasta, a nie analizę naukową jego rozwoju społeczno-ekonomicznego. Z nowinek

75 Ibidem, s. 6.

${ }^{76}$ Ibidem, s. 299. 


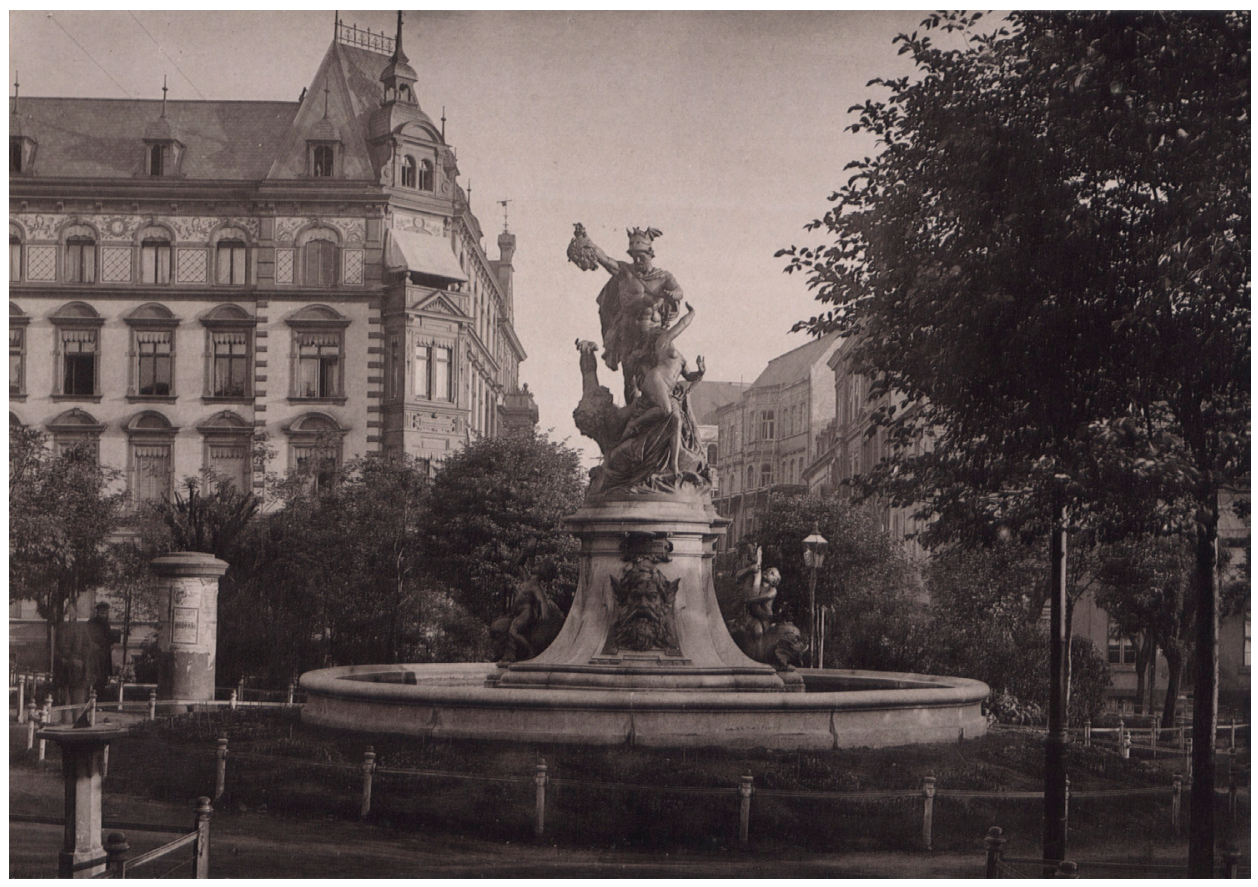

Il. 11. Plac Królewski (dziś pl. Cyryla Ratajskiego) - fotografia Józefa Engelmanna z około 1890 roku z albumu Kunstverein Posen

Źródło: zbiory Biblioteki Uniwersyteckiej w Poznaniu.

obyczajowych interesujące dla Mottego okazują się np. dzieje stosowania tabaki i tytoniu, od których zapewne, śladem swego ojca, nie stronił, czy niewątpliwie intrygujący - wynalazek dagerotypu (fotografii), na którego temat pozostawił szeroki wywód ${ }^{77}$.

Poznańska epopeja pełna jest dygresji przybliżających atmosferę i ducha XIX-wiecznego miasta, jego życie codzienne (pracę, szkołę, funkcjonowanie wielu instytucji itd.), towarzyskie, obyczajowe (wesela, bale, koncerty, spotkania bazarowe, odczyty, spacery mieszkańców, moda, tabaka itd.), ewolucję w kierunku nowoczesności (zmiany w strukturze miasta, przebudowy, modernizacja).

Dla współczesnego odbiorcy, a zwłaszcza badacza, dużym uchybieniem w narracji, jeśli traktuje się Przechadzki po mieście jako źródło, jest brak numeracji, która pozwoliłaby na dokładniejszą lokalizację obiektów, miejsc zamieszkania opisywanych bohaterów czy funkcjonowania organizacji, redakcji czasopism itd. Zrozumiałe jest to z punktu widzenia konwencji przyjętej przez Mottego, zakładającej bezpośrednie zetknięcie

77 Ibidem, s. 127, 142-145. 
z mijaną zabudową miasta. Spacerując ul. Podgórną informował współtowarzysza: „Po drugiej stronie [...], z dołu idąc, masz najpierw ten mały bezpiętrowy domek [...]" 78 lub podawał dla orientacji, głównie sobie współczesnych, nazwisko właściciela kamienicy.

\section{Literackie wartości dzieła}

Przechadzki po mieście są dziełem o szczególnych walorach literackich. Jak wcześniej wspomniano, Motty posłużył się gawędą jako formą narracji. Wprowadził jednak swoiste novum w postaci urozmaicającego wypowiedź - upozorowanego dialogu. Snując opowieść, nie oczekiwał od fikcyjnego Ludwika komentarza, polemiki czy riposty. Zaznaczył jedynie obecność współtowarzysza przechadzek ${ }^{79}$.

Gawęda jako gatunek prozy epickiej wiąże się z kulturą szlachecką. Pierwotnie była głównie opowieścią ustną do literatury pisanej wprowadził ją romantyzm za sprawą Ignacego Chodźki (Obrazy litewskie) i Henryka Rzewuskiego, którego Pamiątki Soplicy są uważane za arcydzieło tego gatunku. Typowe dla gawędy cechy, jak brak ram kompozycyjnych, swobodny charakter, powtórzenia, zwroty do słuchacza, pojawiają się i w relacji Mottego ${ }^{80}$.

Przechadzki po mieście stanowią świadectwo pisarskiego mistrzostwa Marcelego Mottego, autor zdołał bowiem zwyczajną relację z przeszłości przeobrazić w niezwykle zajmującą gawędę. Apologia minionego czasu wyrażona została przez patetyczno-liryczny styl. Nuta sentymentu, elegijny ton są nieodłącznymi cechami jego narracji. „Piewca Poznania” odwołuje się do uczuć patriotycznych, wrażliwości odbiorcy na sprawy narodowe, prezentując szczególnie zasłużonych, podaje gotowe wzorce postępowania. Niejednokrotnie ich dokonania wyolbrzymia przez zabiegi językowe, by stały się bardziej jaskrawe, wyróżniające z galerii wielu innych mniej ważnych $\mathrm{w}$ dziejach miasta postaci. Motty przemawia

${ }^{78}$ Ibidem, s. 381.

${ }^{79}$ H. Wróbel, Marceli Motty jako kronikarz XIX-wiecznego Poznania, Poznań 1968 [maszynopis], s. 84, uznaje, iż Motty mógł posłużyć się podobnym chwytem dialogowym, wzorując się na Diable kulawym Alaina R. Le Sage'a - nawet w Przechadzkach po mieście, zwracając się do Ludwika, wspomniał, że ten utwór jest mu znany; M. Motty, Przechadzki..., t. 2, s. 91.

${ }^{80}$ Gawęda, w: Słownik terminów literackich, red. J. Sławiński et al., Wrocław 1988, s. 163. Gawęda zaistniała też w poezji (m.in. fragmenty Pana Tadeusza Adama Mickiewicza czy poematy Władysława Syrokomli). W drugiej połowie XIX wieku gawędę stosowało wielu ludzi pióra w celach stylizacji. 
językiem swej warstwy społecznej, która - wykształcona - szukała okazji do wykazania się swą erudycją.

Pod względem stylistycznym Motty może być postrzegany jako poliglota. Przechadzki noszą wyraźne piętno wpływów klasycznych. Przejawiają się one nie tylko w składni łacińskiej, ale też w występowaniu znacznej liczby latynizmów: słów („exercitia”, „lingwa” czy „amicus”), zwrotów („pro publico bono", „temporibus quondam”), cytatów („Dubius vixi, incertus morior, Ens entium, miserere mei"). Nadużywanie imiesłowów oraz konstrukcji zdaniowych z czasownikiem zwrotnym sugeruje wpływ języka francuskiego, co nie dziwi czytelnika znającego Listy Wojtusia. Częstym zabiegiem jest również stosowanie czasu zaprzeszłego, np. "ożenił się był”, sugerującego wpływ języka staropolskiego oraz języka niemieckiego. Zdarzają się też germanizmy, np. ",medycyner” „sztubenbursza”, „spruchy”, czy galicyzmy: „dyrectorat”, „elew” ${ }^{11}$. Zastosowane przez Mottego obce zwroty, makaronizmy umiejętnie wplatane, nie zakłócają polskiego tekstu, lecz go urozmaicają.

Język Mottego obfituje w różnego rodzaju neologizmy, np. „dyrektorować", ,"mentorować”, ,pastorować", ,daguerotypować”, „faktorować”, "fotografista”, oraz sporą liczbę wyrazów plastycznie skonkretyzowanych, m.in. "przerąbać się", "puścić się zawodem nauczycielskim” czy "chwycił się matematyki". Zwracają uwagę liczne zdrobnienia, które nie mają jednak zabarwienia uczuciowego, wiele z nich wiąże się z obszarem ekonomicznym lub prawnym, np. „fundusik”, ,'śledztewko”, ,kapitalik”, „handelek”, "folwarczek”, „kupczyk”, „sumka”. Atrakcyjność narracji podnoszą rodzime elementy gwarowe stanowiące językowo-stylistyczny dokument epoki i regionu (np. „węborek”, "perka”, „,szońda”, ,"westka”, "tytka") ${ }^{82}$. Pod względem stylistycznym wyróżniają się opisy poszczególnych postaci zawierające omówienie charakteru, zachowania, wyglądu zewnętrznego, ubioru, np.: „Sam pan adwokat, człowiek dość wysoki, prawie zawsze $\mathrm{w}$ długim granatowym surducie, niskim kapeluszu o szerokich piórach, z fizjonomią gładką poważną i zadowoloną, bez nauk uniwersyteckich $[\ldots]^{\prime \prime 83}$. Wielokrotnie Motty dowodzi swej niesamowitej spostrzegawczości i pamięci wzrokowej. Z bystrością obserwacji idzie w parze błyskotliwy dowcip uwidoczniający się na każdym kroku. Autor nieraz jest dyskretny, życzliwy, innym razem pobłażliwy, na granicy

${ }^{81}$ M. Paluszkiewicz, Przyczynki do słownictwa wielkopolskiego, "Język Polski” 1955, R. XXXV, s. 78.

${ }^{82}$ Wspomina te zagadnienia także Z. Grot, Przedmowa..., s. XXXVIII. Wymienione przykłady pochodzą z obydwu tomów Przechadzek.

${ }^{83}$ M. Motty, Przechadzki..., t. 1, s. 141. 
uszczypliwej ironii. Zwłaszcza w opisach osób, których Motty nie darzył sympatia, wśród których czołowe miejsce zajmują przedstawiciele społeczności niemieckiej lub z nią sympatyzujących. O córkach Stoca Motty zgryźliwie nadmienił, że zostały „wedle modły wyższych sfer niemieckich zręcznie wytresowane" ${ }^{\prime 4}$. Natomiast panią Roerową, znajomą rodziców i babki, podsumował: „była miłym i ciekawym zabytkiem minionych czasów" ${ }^{\prime 85}$.

Zbliżone z konieczności treści biograficzne starał się autor ubierać w odmienny kostium stylistyczny, dzięki czemu nie przypominają słownikowych biogramów. Uderza bogactwo przenośni, niebanalnych określeń, epitetów, porównań. Ze skarbnicy mitologicznej Motty czerpał wielokrotnie, m.in. w opisie dyrektora Vogta: „był bowiem nie tylko muz zwolennikiem, lecz i ojca Bachusa [...], z bożkiem Plutusem w ustawicznych żył zatargach" ${ }^{\prime 86}$. W innym miejscu przy okazji opowiadania o Bazarze Motty skonkludował żartobliwie: „Ale dość już o sprawach Euterpy, panie Ludwiku; ponieważ młody jesteś i masz ruchawe nogi, wolałbyś może usłyszeć coś o Terpsychorze na bazarowej sali"87. Teatr Miejski nazwał Motty przewrotnie "świątynią niemieckiego Apollina" 88 .

Jak większość autorów Motty miał ulubione wyrażenia, wielokrotnie z upodobaniem powtarzane, np. „ostatnimi czasy”, "ile pamiętam”. Miał tendencję do nadawania rzeczownikom w liczbie mnogiej końcówki świadczącej o swoistej archaizacji, np. „uniwersyteta”, „kursa”, „egzamina”, „procesa”, "półbogi”, czy operowania wadliwymi liczebnikami (np. „,kilkaset gimnazjastów”, „z dwoma dziećmi”). Te językowe uchybienia z punktu widzenia dzisiejszej gramatyki w niczym nie rażą czytelnika i nie obniżają wartości tekstu.

Wędrując ulicami, Motty wykazuje się wiedzą i nieprzeciętną pamięcia, zdradzającą felietonistę w stylu prusowskim sprzed lat. Jest jednak sporo tematów, które chętnie powtórzył z przeszłości, poruszonych już w Listach Wojtusia, m.in. spotkanie z Joachimem Lelewelem czy wspomnienie przedstawień teatralnych, koncertów, bali. Nie jest wykluczone, iż by oddać szczegóły życia poszczególnych postaci, zwłaszcza tych, które znał mniej, mógł posłużyć się drukowanymi w prasie nekrologami (wspomnieniami pośmiertnymi).

\footnotetext{
${ }^{84}$ Ibidem, s. 380.

${ }^{85}$ Ibidem, s. 135.

${ }^{86}$ Ibidem, s. 196.

87 Ibidem, s. 91.

${ }^{88}$ Ibidem, s. 194.
} 
Typowe dla Mottego są dygresje, wtręty w tok narracji. Pojawiają się „wycieczki epizodyczne”, odwodzące czytelnika na chwilę od zasadniczego wątku.

Niezwykła komunikatywność narracji, bogactwo języka, a także nasycenie wypowiedzi humorem $i$ anegdotą wraz z ogromem informacji na temat Poznania i jego mieszkańców XIX wieku sprawiają że Przechadzki po mieście stanowią jedyne w swoim rodzaju źródło pamiętnikarskie, którego lektura każdorazowo wnosi nowe treści i wątki zaskakujące czytelnika.

W całości Przechadzki wydane zostały trzykrotnie, po raz pierwszy w latach 1888-1891, następnie w 1957 roku oraz w roku 1999, czyli ponad 100 lat po śmierci autora. To ostatnie wydanie jest rezultatem badań naukowych, zwłaszcza z zakresu biografistyki wielkopolskiej, przeprowadzonych przez prof. Witolda Molika. Staranne opracowanie pod względem merytorycznym, graficznym i ilustracyjnym podniosło atrakcyjność, a co najważniejsze - przydatność dzieła. Przedrukowano tekst Posłowia Zdzisława Grota z poprzedniej edycji z powodu jego walorów narracyjnych. Wydanie z 1957 roku wzbogacone było dodatkowo o indeks rzeczowy, którego nie uwzględniono w najnowszej reedycji.
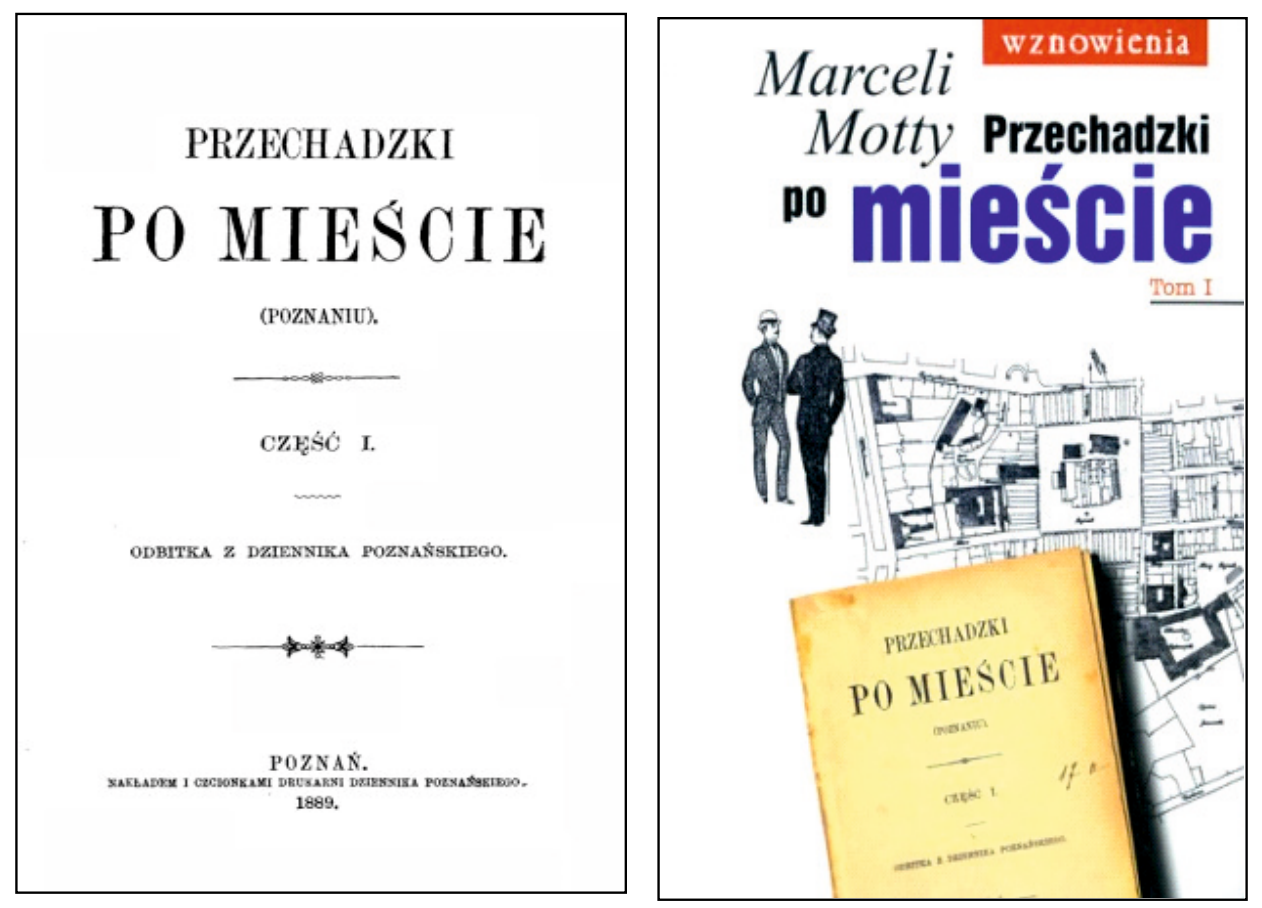

Il. 12. Pierwsze i ostatnie wydanie Przechadzek po mieście - okładki pierwszych tomów Źródło: zbiory autorki. 
Wiekopomne dzieło Mottego z pewnością inspirować będzie kolejne pokolenia miłośników wspomnień oraz historii i jej bohaterów z nadwarciańskiego grodu, tak bliskiego sercu autora Przechadzek po mieście.

\title{
Nineteenth century Poznań and its inhabitants in the diary format chronicle Przechadzki po mieście by Marceli Motty
}

\begin{abstract}
Aвstract. This article presents one of the most important Polish books in the diary format originated in the 19th century - Przechadzki po mieście (City Walks) authored by Marceli Motty, a well-known indefatigable eulogist of the nineteenth century Poznań, within the context of the image of the city and its inhabitants presented in the work. In his memoirs, the author aims at primarily investigating individual people's lives, while the city of Poznań, its streets and squares, simply provides a background and a framework for successive "walks" in the adopted narration. The extraordinary virtues of the book, such as the fluency and richness of the language, sense of humour, narrative clearly energized by powerful anecdotal message, as well as an enormous amount of information on Poznan and its inhabitants (i.e. members of all of the nationalities present in the city), including primarily representatives of the local landed gentry, intelligentsia, and bourgeois class, make this work an outstanding source of its own kind of the venerated author's personal record of events and impressions. This is a book to be savoured slowly for its richness and depth, rediscovered again and again with each rereading of the book, while its contents have been extensively and continuously explored by historians, city tour guides and all those interested in the history of the capital of Greater Poland in the nineteenth century.
\end{abstract}

Key words: diaries, Marceli Motty, Przechadzki po mieście, Poznań, biographies. 